УДК 39(=16)(470)"18"

$316.722(=16)(470) " 18 "$

Др Мария ЛЕСКИНЕН

\title{
ХАРАКТЕРОЛОГИЯ СЛАВЯН В РУССКОЙ ИНТЕРПРЕТАЦИИ: СПОСОБЫ ИЗОБРАЖЕНИЯ ГЕНДЕРНЫХ ТИПОВ „ЭТНИЧЕСКОГО ДРУГОГО“ ВО ВТОРОЙ ПОЛОВИНЕ ХІХ В.
}

\begin{abstract}
Подзаголовочные данные: в статье рассмотрены основные положения теории и практика европейских народоописаний XVIII-XIX вв., а также репрезентации славянских народов в российском народоведении (этнографии) второй половины XIX в. В центре внимания - сравнительные характеристики и образы женских этнических типов западных (польки), южных (сербски) и восточных (малороссиянки) славян.
\end{abstract}

Ключеые слова: русская этнография XIX в., славяноведение, национальный характер, гендерные типы, имагология, антропоэстетика

\section{Европейские традиции репрезентации этнического} Другого в XVI-XVIII вв.

Традиция этнокультурных описаний народов восходит еще к античности. До конца XIX в. они являлись важной частью географических сочинений и записок путешественников, часто их помещали в специальный раздел историко-этнографических трудов, они составляли важную часть дипломатической переписки, военных отчетов и т.п. В эпоху Возрождения востребованность сочинений, включающих народоописания, резко возросла - во-первых, в связи с расцветом жанра космографий и путешествий, и, во-вторых, под влиянием морализаторской (параэтической) литературы, нацеленных на формирование социального этоса и религиозного идеала, которые требовали примеров антиобразца. В этом качестве использование информации о Других оказалось эффективным: сведения о чуждом быте и нравах представлялись весьма красноречивыми. В Европе XVII-XVIII вв. описания народов становятся популярной и востребованной разновидностью занимательного чтения, полезного как для образования и воспитания, так и в более конкретном плане - зачастую они служили вполне адекватными пособиями для послов, путешественников, купцов, дворян и др., предоставляя сведения (более или менее точные или полностью мифологизированные) об особенностях поведения других европейских и неевропейских народов, их обычаях, национальном нраве/характере, образе жизни, отношении к „чужим“ и т.п. 
Несмотря на то, что новая, возникшая в период Возрождения, гуманистическая традиция нравоописаний известных в христианском мире народов складывалась на протяжении XVI-XVII вв., ${ }^{1}$ информация о них все еще носила общий и ознакомительный характер; значимость упорядочивания уже имеющихся сведений для составления характеристик не только вновь „открываемых“, но и давно известных народов Европы и Азии была осознана лишь в середине XVII в., - как следствие необходимости осмыслить резкое расширение пространственных границ обитаемого мира. Именно к этому времени относится появление масштабных трудов европейских интеллектуалов (гуманистического круга и протестантского вероисповедания), целью которых было не только собирание как можно большего числа сохранившихся и новых источников, но и конкретное сравнение народов (в том числе для установления человеческих „видов“ и типов - по аналогии с каталогизируемым в это время животным миром) по совокупности избранных критериев. Ученым той эпохи казалось бесспорным, что эти отличительные признаки - всегда внешние, „заметные“ и потому очевидные.

Вначале эти нарративы являлись органической частью географических трудов - своеобразных „Космографий“ Нового времени, однако постепенно начинает складываться самостоятельное, отдельное направление народоописаний как таковых, которые в период Просвещения выделятся в специальные „народоведческие“ или этнографические исследования.

Сведения о физическом облике, нраве и быте славянских народов в это время включаются в сочинения „о характере“ или „об образах“ европейских народов, ${ }^{2}$ однако наиболее подробных характеристик, как правило, „удостаиваются“ те из них, которые имеют собственную государственность - прежде всего это поляки и „московиты“. Гораздо большее разнообразие этнической карты славянского мира представлено в географических описаниях „окраин“ Европы, пограничных с Азией и Россией (Балкан в том числе) - но не в сравнительно-описательном ключе, а, скорее, в жанре наблюдений путешественников над жизнью и бытом нецивилизованных племен. ${ }^{3}$

Среди многочисленных сведений об образе жизни европейских народов в сравнении ${ }^{4}$ выделим лишь некоторые области, важные для нас в контексте избранной темы. Прежде всего следует упомянуть непременное описание черт внешности, которые кажутся авторам этнически-типичными: это рост, цвет лица, глаз и волос; особенности походки, мимики и жестикуляции, иногда внимание привлекает умение танцевать и фехтовать (которое свидетельствует о таких физических особенностях как пластичность, грациозность или их отсутствие); социальные и региональные отличия в одежде и атрибутах (оружие, украшения). Следующим немаловажным „пунктом“ народоописаний становится характеристика нрава народа, которая фиксирует темперамент, нравственные добродетели и пороки, пристрастия, обычаи, форму правления, умственные свойства, степень религиозности и т.п.

Наконец, еще одной непременной составляющей данных сочинений становится упоминание о характерном облике и занятиях женщин - представительниц описываемого этноса. Это, как правило, довольно краткие высказывания, иногда на уровне общих сентенций, содержат сведения о 
красоте и грации, а также о талантах „общения“ и нормах поведения. Они касаются, впрочем, чаще всего дам знатного происхождения и состоят из оценочных суждений, обусловленных представлениями своего времени о женском предназначении и стандартах светского придворного поведения и хорошего тона.

Эта совокупность качеств и черт, ныне определяемая как „национальный характер“, была призвана установить главные отличительные особенности народа, некую концентрированную его сущность, которую в конце XVIII-XIX вв. назовут „духом“, „душой“ или „физиономией“ народа.

Для адекватного анализа текстов данного жанра необходимо иметь в виду некоторые важные как вербализованные и осознаваемые, так и бессознательные психологические установки наблюдателя в отношении Другого, которые хорошо известны современным антропологам и этнологам. ${ }^{5}$ Это, во-первых, доминирование описательного метода и убежденность в адекватности считывания этнокультурной специфики методом визуального наблюдения. Во-вторых, это каузальная атрибуция - „установка ожидания“: зависимость впечатлений о Другом от сформированных в культуре наблюдателя этнических и цивилизационных представлений, предубеждений и стереотипов. Для этнографических нарративов данного жанра характерно проявление еще одной (универсальной) концепции, обуславливающей явные и скрытие оценки и суждения авторов - это этноцентристкая убежденность в превосходстве европейской христианской цивилизации и собственной национальной культуры. ${ }^{6}$ Наконец, в описаниях европейских народов этого времени важной теоретической посылкой выступала трактовка прямого соответствия внешних примет внутренним качествам человека или социальной группы. Кроме того, считалось, что свойства „нрава народа“ всегда легко могут быть воплощены в некотором типичном его представителе, ${ }^{7}$ и потому обобщенный образ народа создавался авторами с той же легкостью, с какой в каждом конкретном представителе этнической группы обнаруживали характерные признаки этничности в целом. Критерием этой произвольно конструируемой типичности становились такие черты Другого, которые воплощали наиболее отчетливые отличия от привычного, „своего“ образа или автостереотипа. Те из них, которые расценивались как максимально несхожие, чаще всего получали статус этнически-типичных (этнодифференцирующих) примет Другого - описываемого этноса.

На протяжении всей истории географических и этнографических описаний идея зависимости образа жизни и характера народа от природных факторов не ставилась под сомнение - даже в XIX веке господства антропогеографической теории. В XVI-XVII вв. природа этноотличительности, ее телесность, непреодолимость и предсказуемость „нрава“ и, в конечном итоге, истории и судьбы народа, тем более казались очевидными. Такая трактовка врожденности имела своим следствием концепцию тесной взаимообусловенности и взаимозависимости антропологического (физического), психического и морального (воплощенного в нраве / характере) параметров этнокультурного своеобразия. Например, описывая французов, барочный автор И. Барклай отмечал, что „ни один человек в мире не обладает природными свойствами (natura), более соответствующими их мужественному поведе- 
нию: самообладание, походка и жестикуляция составляют единое целое. (...) Тщетно соседние народы надеются обрести их облик и подражать их поведению, напрасно они раболепно копируют их одеяния и манеры, не ведая, что все они - плод того же гения“ (под „гением“ Барклай понимал „дух“ или „идею“ народа ${ }^{8}$ ), и потому „другие в нем (в этом образе. - М. Л.) смешны“. Это дает автору повод порассуждать о возможности и перспективах восприятия и заимствования одними народами качеств (прежде всего добродетелей) других. Такого рода попытки представляются ему безуспешными, так как указанные этнические свойства и внешность определяются врожденными способностями и телесными „привычками“: „Мы можем легко скрыть смирение, ненависть, любовь или благочестие. Но то, что не создано властью ума, а порождено обычаем или (способом. - М. Л.) проявления способностей, соответствующих телу, вы никогда не сможете подделать, ведь против этого - сама Природа“. 9 В переводе на современный научный язык это означает, что этничность „встроена“ в телесность и передается генетически, она не только воплощена (буквально „инкорпорирована“) в физическом теле, но и „закрепощена“ им; нельзя имитировать или „представлять“ этническое поведение. Барклай, в сущности, формулирует ту самую идею нерасчленности физического и духовного, которая в трудах социальных антропологов XX в. обретает статус исследовательского подхода, позволившего по-новому рассматривать связь материального и социального: М. Мосс вводит понятие «техники тела“, а в работах П. Бурдье она выступает элементом „габитуса“. ${ }^{10}$

Заключения автора XVII в. представляются весьма значимыми, так как они дают возможность объяснить еще одну характерную закономерность в систематизации рассматриваемых донаучных этнографических репрезентациях: поскольку нравственность и традиции „встроены“ в человеческое тело и воспроизводятся бессознательно, постольку физический облик не только не в состоянии скрыть темперамент, ум, добродетели и пороки, но, напротив, неизбежно „разоблачает“ их. Поэтому принцип изоморфизма, взаимообусловенности внешних и внутренних качеств обрастает новыми нюансами и расширяет сферу применения.

Еще одним следствием такой установки является значение внешней красоты в этнических описаниях и изображениях (как вербальных, так и визуальных). Красота, с одной стороны, видится непременным признаком „своего“ этнического типа (или одного из его региональных вариантов) в самоописании, которое, в свою очередь, неизбежно осуществляется в соответствии с установкой естественного этноцентризма. С другой, красота, как и в античности, выступает „доказательством“ добродетельности или связи с Божественным, в то время как безобразие видится приметой порока или контактов с „дьявольским“, потусторонним, нечистым или чужим (как в традиционной культуре). В-третьих, физическое и нравственное совершенство ассоциируется с социальным статусом человека и группы, оно объявляется присущим лишь знатному сословию, поэтому считается, что „низы“ - как другая „порода“, не могут обладать такими чертами, и в этом смысле социальная и этническая инаковость сближаются (бытовало, в частности, убеждение, что бастарды, как и метисы, легко узнаваемы в связи с тем, что они принимают признаки „низшего“ из родителей). Наконец, в-четвертых, 
восприятие иноэтнической внешности подчиняется определенным стереотипам и предубеждениям - наблюдатель „несвободен“ в своих антропоэстетических оценках, ${ }^{11}$ и, следовательно, фиксация „красивого“ и „некрасивого“ в этнографических описаниях является характеристикой в первую очередь представлений наблюдателя, а не его объекта.

Принцип изоморфизма в этнических репрезентациях разного уровня позволяет увидеть общие принципы человеко- и мироустройства в целом: как климат определяет характеры народов, их благосостояние, которые, в свою очередь, воздействуют на сочетание пороков и добродетелей, заметных в антропологическом типе. Поэтому по одной или нескольким приметам, по мнению описателей, возможно составить цельный образ, реконструировать или спрогнозировать недостающие или неизвестные этнодифференцирующие признаки и качества. Это приводит к еще большей произвольности в оценках наблюдателей, путешественников и несведущих авторов.

Особое место в характеристиках Других занимает установление особенностей физического облика женщин. Не всегда, впрочем, их привлекательность интересовала авторов-мужчин. До Возрождения женская красота вовсе не являлась ни предметом восхищения, ни предметом поклонения; вплоть до XVIII в. она воспринималась, как и мужская, неотделимой от моральных добродетелей. Всякое физическое совершенство исключало, согласно господствующим воззрениям, душевное уродство, а „всякий изъян внешности свидетельствует о внутреннем пороке“. ${ }^{22}$ Эта доминанта, в сущности, делала вовсе необязательной фиксацию своеобразия женского этнического облика, ибо он в той или иной степени отражал специфически-этнические свойства в той же степени, что и мужской.

Традиции визуальной „этнической имажинерии“ - то есть создания изображений разных европейских народов в их узнаваемом и одновременно стереотипном воплощении складываются в XVI в., в них гендерные этнические образы занимают важное место, однако наиболее интересными для читателей оказываются экзотические и яркие приметы инаковости - такие как одежда (в связи с чем они и получили именование „костюмов“), социальные и статусные атрибуты и некоторые приметы сословной принадлежности. ${ }^{13}$ Женские образы в этой иконографической характерологии вплоть до конца XVIII в. носили более символический, нежели реалистический характер - так или иначе, антропологические признаки этноса находили в них весьма условное отражение; можно даже говорить об определенной „обезличенности“ женского облика, в визуальных изображениях отчетливо заметен акцент на материальных, вещественных атрибутах этничности и гендера. ${ }^{14}$ В бо́льшей мере в них проявились расовые приметы телесности, трактуемые, впрочем, также в аксиологическом ключе - посредством категорий оппозиций цивилизованность / варварство, культура / дикость, Запад / Восток и др.

Один из наиболее известных источников, объединивший в себе визуальную и вербальную формы национальной характерологии и продолживший традицию сравнительного описания европейских народов, датируется приблизительно концом XVII-началом XVIII вв. Он озаглавлен как 
„Краткое описание пребывающих в Европе народов и их свойств“15 и представляет собой таблицу различных черт десяти европейских народов (в том числе русских и поляков). Критериями сравнения выступают 17 примет, выраженных в односложной формуле-характеристике. Это - определения особенностей образа жизни, поведения и свойств нрава, которые условно можно разделить на несколько групп: 1) географическое и климатическое своеобразие региона проживания, традиции государственного устройства и конфессиональной принадлежности жителей: „облик страны“, „признание своим государем“, „богослужение“; 2) традиции и физические „слабости“ „обычаи“ и „болезни“; 3) самая большая группа - качества, которые касаются свойств характера / нрава народа: „природа и свойства“, „проявления этих свойств“, „разум, „наука“, „пороки“, „любовь к...”, „воинские добродетели“, „пристрастия“, „времяпрепровождение“; 4) внешние признаки зафиксированы только опосредованно - в рубриках „одежда“ и „сравнение с животными“. Впрочем, последний пункт (кстати, часто встречающийся и в более ранней традиции народоописаний) в равной степени содержит в себе „намеки“ не только на внешние приметы, но и на особенности характера. Несмотря на отсутствие в таблице определений, касающихся физического облика представителей европейских этносов (информация о них исчерпывается визуальным изображением мужских национальных костюмов, что делает словесный комментарий избыточным), зооморфные уподобления этнических типов дают представление не только о символах, но и о типичных антропологических приметах и нравственных особенностях, воплощенных в собирательном образе звериной ипостаси, что в XIX -XX вв. получит широкое распространение в национальной символике, аллегоризациях и регионально-государственных зооморфных отождествлениях ${ }^{16}$ В упомянутой таблице, например, поляк сравнен с медведем, русский - с ослом, венгр - с волком, француз - с лисой.

Несмотря на очевидные изменения в теории и практике описаний народов в эпоху Просвещения основные постулаты и подходы оставались неизменными: это географический детерминизм (который благодаря работам Ш. Монтескье распространялся теперь на „склонность“ наций к типам политического устройства), метафора стадиальности человеческой жизни, применяемая к народам для определения стадии их цивилизованности, изоморфизм внешних и внутренних признаков, зооморфические подобия. Последние два принципа были детально развиты в теории индивидуальной и социальной физиогномики (которая распространялась и на способы изображения этнических групп) - в частности, в трудах И. К. Лафатера и в описаниях так наз. сословных „типов“,17 остававшимися популярными вплоть до середины XIX века. Теория соответствия внешних черт внутренним качествам человека начиная с Просвещения находилась под воздействием интерпретации категорий прекрасного и безобразного в немецкой философии этого времени, выходя за рамки узко-эстетической проблематики и эволюции представлений о стандартах моды и красоты, столь актуальных для данной историко-культурной эпохи. Все они оказали серьезное воздействие на стандарты визуальной и вербальной репрезентации народов в западноевропейской и русской культуре и этнографии. 
На уровне обывательских взглядов характерология (учение о национальных характерах) претерпела в то время весьма незначительные изменения в сравнении с предшествующими эпохами. В качестве примера можно привести „Опись качеств знатнейших европейских народов“, содержащуюся в знаменитом и многократно переиздававшемся на протяжении столетия „Письмовнике“ Н. Г. Курганова (впервые - 1769 г.). ${ }^{18}$ Это описание не является, разумеется, оригинальным сводом национальных качеств в русском восприятии, а, напротив - авторским переложением стереотипных представлений европейцев друг о друге, формировавшихся начиная с XVI в. ${ }^{19}$ Курганов поместил описания различных сторон нрава только пяти западноевропейских народов. ${ }^{20}$ Из 14 пунктов сравнения, общий принцип которых восходит к „Доске народов“, внешности отданы лишь три - „ростом“, „лицом“ и „в одежде“, доминируют по-прежнему качества, связанные с характером, при том, что введен отдельный пункт „нрав“. Из совершенно новых параметров обращает на себя внимание фиксация гендерных особенностей - рубрики „в браке“ и „женщины“. Характеристики женщин касаются, однако, не внешности, а нрава и положения в семье - точнее, в отношениях с мужем („гордые“, „злые“, „своенравные“ или „домовые“ и „податливые“).

В целом следует с высокой долей уверенности констатировать, что этнонациональные черты и свойства женщины как отдельный и значимый для народоописателей элемент характеристики обретает своеобразную легитимацию именно с эпохи Просвещения. Можно предполагать, что немаловажную роль в этом сыграла, с одной стороны, сохранявшаяся с раннего Нового времени тенденция к сочетанию образовательных и морализаторских функций этого жанра, а, с другой - новое представление эпохи Просвещения о роли женщины в семье и ее ответственности за воспитание детей. Сатирический элемент в так наз. „криках“ или „физиономиях“ („типах“), вербальных описаниях разных народов и в их визуальных изображения ${ }^{21}$ довольно долго сохраняется в европейских репрезентациях Других в XIX в., а борьба поборников религиозной и светской морали зачастую была нацелена именно на исправление поведения и сохранения нравственности женщины.

Складывание этнографии как самостоятельной дисциплины начиная с конца XVIII в. поставило задачу упорядочивания сведений о народах - как собранных ранее, так и впервые вводимых в научный оборот, что привело к необходимости выработать теоретически обоснованные стандарты изложения данных об этносах, а также сформулировать способы их изучения. Описание в естественно-научном знании того времени выступало главной формой собирания этнографических данных и одновременно - основным методом исследования. Изучить означало представить подробную характеристику объекта, выполненную в определенной последовательности и по вопроснику, чтобы в конечном итоге определить место данного объекта в существующих таксономических иерархиях. Этим же правилам подчинялось и описание человеческих сообществ. $^{22}$ Большая часть параметров, подлежавших фиксации, впрочем, осталась прежней: это внешний облик, нрав или характер, формы политического устройства. Новыми факторами стали прежде всего язык (благодаря теориям немецких просветителей) и фольклор (которым начали интересоваться прежде всего романтики), а с 1840-х гг. - и материальная культура народов. 
Быт и нравы народов в изображениях XIX в.:

влияние научно-этнографических теорий

Особенностью народоописаний XIX в. было признание равноценности научных нарративов и научно-популярных очерков и свидетельств очевидцев. В географо-статистические обзоры европейских стран (и Российской империи в том числе) включались фрагменты мемуаров, записки путешественников предшествующих столетий, путевые впечатления и заметки современников, репортажи, отрывки из художественных произведений. В России даже во второй половине столетия, когда складывается предметное поле и методы этнографии как самостоятельной дисциплины, в строго позитивистские описания страны по регионам и в многочисленные очерки народов зачастую помещалась одна и та же информация из разножанровых источников. Субъективные впечатления наблюдателей, сведения, собираемые волонтерами по академическим вопросникам, суждения других описателей, заключения и выводы образованных путешественников представлены как равнозначные и объективные в этнографическом отношении. Отличиями русских этнографических народоописаний этого времени можно считать, во-первых, стремление упорядочить данную информацию в соответствии с программой сбора сведений по этнографии Н. И. Надеждина; во-вторых, „власть номинаций“ над претендующими на объективность мнениями наблюдателей-исследователей, когда известные классификации языков и культур заставляют автора видеть предписанное, усматривать ожидаемое и узнавать знакомое; и, в-третьих, объявление только одного - крестьянского - сословия носителем антропологических, традиционных и поведенческих черт языка, быта, культуры и нрава этноса. ${ }^{23}$

В 1870-80-е гг. на научные исследования народов активно влияют заключения и теории антропологического знания (физической антропологии), позволяющие во многом пересмотреть имеющиеся данные о происхождении и родстве этносов. Результаты массового измерения физических параметров этнических групп, количественные методы обработки этих данных и особенно расцвет краниологии обусловил эволюцию расовой теории. В русской науке того времени термин „раса“ понимался неоднозначно, он использовался и в значении „племя“, „народ“ (синонимичном современному пониманию „этноса“). ${ }^{24}$

Расовые в самом широком смысле (т. е. антропологические) отличия во второй половине XIX в. вполне поддавались определению точными методами, что укрепляло убежденность в возможности объективного описания и оценки физических качеств этнической группы. Полемика касалась вопросов о происхождении расовых отличий, критериев их классификации и тех свойств и признаков, которые определяют эволюцию развития народов и уровень их цивилизованности. На практике (т. е. при полевом исследовании) профессиональные антропологи и неподготовленные наблюдатели могли лишь в самом общем виде зафиксировать на письме или в изображении кажущиеся им характерными особенности физического облика представителей разных рас и народов - это по-прежнему цвет кожи, глаз и волос, рост, черты лица. В описаниях физического облика доминируют ар- 
хаические оценочные определения, связанные, во-первых, с эстетическими и вкусовыми предпочтениями тех, кто стремился дать научно-объективное описание в наименее приспособленных для этого терминах и категориях (например, красивый/некрасивый), и, во-вторых, все с теми же моральными свойствами (добрый/злой, нежный/грубый, честный/лукавый) или особенностями темперамента (веселый/угрюмый, энергичный/едлительный, бодрый/вялый). ${ }^{25}$ В некоторых этнографических и антропологических вопросниках-анкетах осуществлялось гендерное разделение описаний этнического облика (широко распространенного, типичного), а также давалось указание обращать внимание на особенности интерпретации эстетических категорий прекрасного и безобразного в изучаемых культурах, в том числе и касающихся физического облика „своих“ и „чужих“.26 Однако в качестве самостоятельного объекта полевых исследований такие представления выступали реже, чем в реконструкциях, предпринимаемых на основании анализа фольклорных текстов этнической культуры. В то же время во второй половине XIX в. появляется множество публицистических статей и научных работ российских ученых и публицистов, в которых признается историческая и социальная обусловленность представлений о женской внешности и физической привлекательности в „высокой“ и народной культуре разных народов на основании изучения текстов народной словесности и художественной литературы. ${ }^{27}$

Восприятие физических параметров, составляющих „физиономию“ народа, продолжало оставаться областью, в которой наблюдатели более руководствовались собственными предпочтениями (индивидуальными, социальными, профессиональными, культурными и др.), нежели „объективными“ данными. Впрочем, и ученые, и путешественники не рефлексировали по поводу того, почему те или иные черты казались им привлекательными или отталкивающими. Только естественным (обывательским) этноцентризмом трудно объяснять данную особенность восприятия, ${ }^{28}$ так как в рассматриваемых нами источниках спектр оценок внешности различных народов Российской Империи весьма широк: в них часто встречаются негативные характеристики физического облика представителей собственного этноса и, напротив, восхищение красотой представителей других народов.

Следует также подчеркнуть и то обстоятельство, что подобные оценки внешней красоты (впрочем, как и иные заключения о характере, нравах и обычаях народов в целом или их отдельных социальных групп, которые составляют совокупность стереотипных суждений авторов этого круга) ${ }^{29}$ ни в коей мере нельзя считать универсально-национальными. Напротив, они демонстрируют особенности эстетического восприятия и модных канонов образованных сословий Европы своего времени. Несмотря на попытки русских авторов, выявить признаки национальной женской красоты посредством анализа фольклорных произведений ${ }^{30}$ в народной культуре вообще и в менталитете русских крестьян в частности, в реальной действительности значимость и критерии физической привлекательности были жестко социально дифференцированы. В традиционных представлениях русских, - констатируют современные антропологи, - красота связывалась исключительно с периодом девичества и целомудрия, а потому „ограничивалась перио- 
дом от совершеннолетия до свадьбы“; а „представления о красоте... сводились, главным образом, к признакам физического здоровья“.31 Красивыми, по мнению крестьян, считались „бойкие“, „веселые“ и задорные девушки. ${ }^{32}$ Рассуждения о чертах лица, формах телах, грации или нравах женщин (как своей культуры так и расовых типов) - это предмет интереса мужчин, принадлежавших к исключительно европейскому кругу и высшему сословию. ${ }^{33}$

Особое место занимал вопрос о гендерных вариациях физического облика (и красоты в том числе) в спорах антропологов. Западноевропейская расовая теория в качестве одного из основополагающих постулатов приняла тезис о том, что критерием цивилизованности и принадлежности к „высшим расам" служит внешняя физическая гармония - разумеется, параметры этой гармонии обусловлены были представлениями об идеале красоты, формировавшимися в европейской культуре еще в эпоху античности. Можно согласиться с современными исследователями в том, что расовые теории в российской этнографии и антропологии не получили такой актуализации, как в западноевропейской науке того времени. ${ }^{34}$ Это, однако, не исключало довольно резких и расистских с сегодняшней точки зрения ${ }^{35}$ высказываний о внешности и нравах некоторых народов Севера России и Сибири. ${ }^{36}$ Стереотипная констатация „некрасивости“ финнов и родственных им финно-угров Поволжья часто была связана с цветом их лица, который казался желтым илиि смуглым, ${ }^{37}$ хотя вызвано такое видение было исключительно теорией, согласно которой финно-угры имели азиатское происхождение (т. е. принадлежали к желтой расе). ${ }^{38}$ С другой стороны, азиатское происхождение не являлось главным критерием оценки внешности представителей этноса. Подтверждением тому может служить описание казанских татар, относимых к народам „азиатским“ (не в географическом, а в цивилизационном отношении). В одном из учебников говорится, что они „по физическим своим особенностям принадлежат к числу красивых пород“.39

Но если в западноевропейской традиции народоописаний акцент на расовом физическом облике был актуален и ярко выражен еще в „доантропологический“ период, ${ }^{40}$ то в русских этнографических очерках второй половины XIX столетия физическое разнообразие этнических типов, их смешение воспринималось как характерная примета имперской полиэтничности - особенно в отношении народов Европейской России. Немаловажным обстоятельством можно считать и то, что сам великорусский тип в процессе его научной реконструкции трактовался как смешанный не только в этническом, но и в расовом отношении. Причем концепция метисации существовала в двух версиях - бесспорной первой, базировавшейся на заключении о том, что великорусы являются финно-славянским субстратом и менее убедительной для современников второй, заключавшейся во влиянии „тюркской“ (т.е. татаро-монгольской) „крови“ на северо-восточных славян. ${ }^{41}$

Таким образом, красота оказывалась не только важным доказательством, критерием цивилизационной „развитости“ народа, но и выступала в качестве этнодифференцирующего признака европейских этносов („кавказской расы“). Несмотря на очевидную субъективность данного критерия, ученые стремились обосновать научные дефиниции красоты. Как уже указывалось, этнические описания женщин традиционно включали оценку привле- 
кательности их лица, тела, движений и походки. В последней четверти XIX в. вышло несколько масштабных по охвату материала трудов, посвященных рассмотрению всех расовых типов женщин с целью выявления принципов гендерной специфики этнического и антропологического обликов (они стали первыми сочинениями по западноевропейской антропоэстетике). Эти сочинения принадлежали перу врачей-гинекологов и путешественников, и, несмотря на „научность“ поставленных задач - объяснить и показать разнообразие типов женской привлекательности/непривлекательности среди представителей всех народов человечества, - содержали в себе очевидные черты этноцентризма и расовых предубеждений. К числу наиболее известных русскому читателю второй половины XIX в. работ принадлежат: сочинение А. фон Швейгер-Лерхенфельда „Женщины Земли“ (1881), ${ }^{42}$ трехтомник Г. Плосса $(1885)^{43}$ и исследование К. Штраца „Расовая женская красота“ (1904). ${ }^{44}$ В них отразились многие довольно распространенные в европейской среде второй половины столетия гендерные и этнические стереотипы. В их ряду необходимо рассмотреть следующие.

Французский скульптор Ш. А. Кордье - современник этих авторов, - в своем докладе, прочитанном перед аудиторией Парижского антропологического общества доказывал, что „всякая раса разнится в присущей ей красоте от другой расы. Поэтому нет общих признаков красоты“. 45 Эту же позицию разделял Г. Плосс, утверждавший, что для мужчины наиболее привлекательной будет казаться представительница его племени и расы, а основным общим условием красоты остается лишь требование здоровья и „нормальности“. 46 С этим соглашались русские антропологи. А. В. Богданов в связи с полемикой о русском типе писал, что „в каждом из нас, в сфере нашего 'бессознательного' существует довольно определенное понятие о русской красоте“.47

К. Штрац же, напротив, не сомневался в том, что любому человеку (т. е. мужчине) всегда физически более привлекательным кажется не свой расовый или этнический тип, а „совершенный тип белой расы“. Поэтому он различал понятия женские „расовые типы“ и женская „расовая красота“. Первые могут быть выражены во всяком представителе этноса, а вторая всегда стремится к эталону белой расы, она „развивается только у того тела“, у которого расовые особенности (т.е. по умолчанию „небелой“ расы) настолько ослаблены, что переходят границы красоты. ${ }^{48}$ Именно идеальный образец „белых“, по мнению немецкого автора, становится главным как сознательным, так и неосознанным объектом сравнения. Поэтому представления о красоте универсальны; „красивыми“ всем мужчинам кажутся те представительницы других народов, чьи параметры максимально близки к этому образцу. ${ }^{49}$

Более взвешенная оценка женской этнической красоты содержится в сочинении предшественника К. Штраца по изучению гендерной антропологии - Г. Плосса, который обладал гораздо более широкими познаниями в этнографии. Однако и Плосс разделял широко распространенное убеждение в „умственном и нравственном“ неравенстве полов, ${ }^{50}$ a, точнее, о женском несовершенстве физиологии, ума и морали. Он принимал расхожий взгляд о преобладании у женщин чувств и эмоций над разумом и логиче- 
ским мышлением (некоторые западно-европейские антропологи, впрочем, и вовсе отказывали женщинам во втором), соглашаясь с уподоблением женщин детям - по уровню их развития, отсутствию рефлексий и природном имморализме. ${ }^{51}$ Не столь жестко Плосс интерпретировал необходимые условия для развития женской красоты, считая, что к ним относятся не только климато-географические факторы, определяющие особенности антропологического облика и физическое здоровье, но и социальные - те, которые формируют положение женщины в социуме, позволяя ей „свободно развиваться“. „Женская красота, - пишет он, - не развивается у того народа, женщины которого с юности низведены к униженному положению домашних животных..." ${ }^{52}$ Кроме того, занятия мужскими промыслами и тяжелым физическим трудом делают трудноотличимой женскую внешность от мужской, особенно с годами. Плосс, однако, не отрицал позитивных последствий метисации для умственного и физического „улучшения породы“ и не сомневался в том, что смешение (но только в ограниченных масштабах) различных рас и народов способствует появлению женских типов, отличающихся признанной красотой и привлекательностью. ${ }^{53}$

Расово-антропологическая коррекция уже сложившихся стандартов характерологических описаний европейских народов, в которых женские образы были лишь дополнительным аргументом и иллюстрацией общеэтнической специфики, не смогли кардинально изменить видение женского этнического типа, но содержание этих описаний и их оценки во второй половине столетия находились под сильным влиянием двух факторов: вненаучного - поэтики романтизма и процессов социальной эмансипации и научного - объявления женского физического типа в наибольшей степени отражающим и сохраняющим устойчивые черты этнической антропологии и культуры.

B XVIII в. и в начале XIX в. части света и связанные с ними оценки цивилизованности и характеристики нравов диктовались позицией наблюдателя, находящегося в Центральной Европе - его точка зрения определяла ориентиры так наз. „ментальной карты“. ${ }^{4}$ Они легко поддавались изменению в зависимости от географического и идеологического „положения“ наблюдателя. Поэтому оппозиции север/юг, запад/восток в эпоху романтизма легко меняли свое семантическое наполнение, приписывая те же характеристики противопоставлению север/запад, ${ }^{55}$ - так же, как в мифе о Европе „Азия“ или „Сибирь“ понимались в первую очередь метафорически, а „восток“ и „запад“ могли оказаться важными маркерами в идентификации „центрального“ и „периферийного“ в пространстве культуры. Это оказало самое непосредственное воздействие и на характеристики этносов, относимых - в соответствии с указанными выше традициями нравоописаний - либо к северу, либо к востоку (югу). Изображение внешних особенностей и нравов этносов выстраивалось в духе евроцентризма. „Южные“ народы выступали носителями „изнеженного“, феминного начала, в то время как северные воплощали маскулинный тип. Поэтому черты, приписываемые женщинам „Востока“ как в европейской беллетристике, так и в литературе путешествий, выбирались из комплекса качеств и особенностей, сложившихся под влиянием ориенталистского дискурса: это опасные покорительницы муж- 
ских сердец, томные одалиски, ${ }^{56}$ однако более сексуально раскрепощенные, чувственные и потому опасные.

Сентиментальная литература путешествий уделяла большое внимание и вопросу о влиянии климата на людей и народы, ${ }^{57}$ но в интерпретации различий „южных“ и „северных“ народов следовала за просвещенческими гипотезами, наделяя обитателей холодного климата большими добродетелями и свойствами „молодости“. Вопрос, повторим, был лишь в отсутствии точного перечня стран или краев севера и юга, что позволяло весьма свободно толковать метафору. И в период господства парадигмы позитивизма характеристики групп народов оставались неизменными, лишь частично подвергаясь корреляции.

\section{Гендерные особенности славянского этнического типа}

Включение в тексты путешествий и научных этнографических очерков описаний внешнего облика женщин можно считать универсальной особенностью народоописательных текстов, что связано с общими принципами конструирования этнического типа. Авторы и составители - мужчины - оперировали при этом оценочными определениями как, например, красивая/некрасивая, обаятельная/необаятельная, страстная/холодная, живая/ вялая, при этом редко поясняя не только природу этой привлекательности/ непривлекательности, но и критерии собственных суждений.

Обращаясь к изображению женщин в русских этнографических народоописаниях, отметим, что они, с одной стороны, всегда вписаны в общую схему этнических характеристик народов Российской империи, и, с другой, соотносятся с традицией этнических самоописаний в национальных историографиях и с русскими гетеростереотипами, однако не теми, которые бытовали в народной картине мира, а со сложившимися в образованных слоях общества - в первую очередь под влиянием художественной и научной литературы. ${ }^{58}$ Самостоятельным и почти непременным пунктом путевых записок, историко-этнографических и географических очерков гендерные характеристики этносов становятся начиная с $1840-$ - гг. ${ }^{59}$ по двум причинам: во-первых, положение женщин и детей в социуме становится важным критерием определения уровня культурного развития общества в целом и крестьянства в частности, а также показателем цивилизованности народа в целом, и, во-вторых, в антропологической науке все большее признание завоевывает концепция, согласно которой женский этнический („расовый“) тип в наибольше степени сохраняет в себе характерные этнические физические и нравственные свойства. ${ }^{60}$ Немаловажную роль сыграли и модернизационные реформы в России, поставившие так наз. „женский вопрос“, 61 далеко не ограничивавшийся женской эмансипацией, ${ }^{62}$ в центр общественно-политических дискуссий. Наконец, довольно резкое изменение традиционных и просветительско-романтических представлений о гендерных моделях и правах повлекло за собой интерес к опыту и практике других народов. В этом контексте показательным примером может служить содержание статьи „Женщина“ в Энциклопедии Брокгауза и Ефрона, посвященной поло- 
жению женщины в культуре народов мира, в разных конфессиональных и исторических традициях. Главный акцент сделан на процессе постепенной эмансипации женщин в гендерном, сословном и культурном аспектах, ${ }^{63}$ a собственно „эмансипации“ посвящена отдельная статья энциклопедии.

Наиболее очевидной особенностью любых этнографических описаний женщин является их социально- и гендерно-субъективный характер, ведь подавляющее большинство авторов были мужчинами, причем принадлежавшими к высшим и средним сословиям. Не затрагивая хорошо изученные ныне универсальные особенности мужского нарратива и вопроса о своеобразии мужского письма „дофеминистической“ эпохи, отметим лишь несколько наиболее существенных отличий в изображении женщин в „мужских“ этнографических текстах. Это, во-первых, архаическое стремление дать не нейтрально-антропологическую, но оценочную характеристику внешней привлекательности наряду с нравственными добродетелями. Во-вторых, - четкая сословная дифференциация, проявляющаяся в разных требованиях к „хорошему“ поведению и достоинствам женщин-крестьянок (как социально „чуждых“ в культурном отношении) и женщин условно „высшего“ сословия (дворянок, горожанок, почти никогда - аристократок и представительниц „высшего света“), некой социальной „ровни“ повествователю. Именно вторые, несмотря на декларации описателей, оказывались главным объектом характеристик. Это важная социальная подоплека, поскольку суждения принадлежали представителям иной гендерной и общественной группы - т.е. внешним наблюдателям (социальному и этническому Другому).

Кроме того, значимым критерием позитивной оценки женщин становится степень их приверженности обычаям и нормам традиционного общества, патриархальным ценностям и социальным практикам. Любые проявления модернизации или эмансипации в этом отношении оцениваются, как правило, негативно. Однако последнее можно объяснить и тем, что задачей описателей было изображение „этнического типа“, призванного воплощать именно „вечные“, константные черты культуры народа, не подверженные сиюминутным трансформациям или моде. Чем консервативнее, архаичнее крестьянская культура, тем более адекватна она этнически-культурной „чистоте“ и типичности. Особенно отчетливо эти особенности заметны в сравнении с текстами этнографических описаний, вышедшими изпод женского пера. Их очерки отличает внимание к положению женщины в семье и социуме, к социально-экономическому и правовому статусу, сексуальной жизни, а также нескрываемое сочувствие к „тяжкой женской доле“ и рабскому положению, сформулированное зачастую с позиции личного опыта и гендерной солидарности ${ }^{64}$ (то есть они воспринимались и описывались с позиции социального „своего“, хотя и этнического Другого).

Обратимся к детальному анализу характеристик женщин в русских народоописаниях славян второй половины XIX века на примере очерков о представителях трех славянских групп - восточных (малорусы), западных (поляки) и южных (сербы). Начать следует с упоминания некоторых важных установок наблюдателей. С одной стороны, их отличала общность принципов описания, обусловленная идеями о типичных качествах земле- 
дельческих и христианских народов, причем согласно просветительским и романтическим представлениям, принадлежавших к категории „молодых“ европейских этносов. Поэтому все славянские народы наделялись добродетелями трудолюбия, гостеприимства, патриархальной честности, мужества и т.п. При этом, как подтверждает сравнительный анализ перечня этноспецифических качеств нрава (характера) славян в европейской и русской славистике XVIII-XIX вв., разработанного еще немецкими философами (главным образом И. Г. Гердером), сравнение германских и славянских племен как типологически противоположных друг другу, как выразителей двух оппозиционных „стихий“ европейской этноплеменной и цивилизационной истории, оставалось неизменным на протяжении полутора веков, лишь детализируясь и дополняясь. ${ }^{65}$ Наиболее принципиальным для эволюции национальных характерологий стало то, что славянам приписывались душевность, мягкость, сердечность и „детскость“ в противоположность рациональному, жестокому, холодному „зрелому“ началу германцев.

Принято считать, что эта столь значимая и константная, по сути, характеристика славянского „нрава“, основоположником которой был Гердер, вполне позитивна - в сравнении с другими, негативными оценками славян его предшественниками и современниками. Однако это не совсем точно: тщательное рассмотрение оппозиций, используемых в авто- и гетероописаниях славянского нрава демонстрирует важное соответствие, связанное с изображением двух „видов“ Другого - этнически-чуждого и гендерного т.е. женского начала. В сущности, женские свойства слабости, эмоциональности, беззащитности, неорганизованности, неразвитого интеллекта и т.п. приписывались славянам, в то время как представители „своего“ - германского племени - выступали как обладатели мужских позитивных качеств силы, рациональности, дисциплины, организации, ума. О. В. Рябов полагает, что это наложило отпечаток на способ изображения национального/этнического, государственного/культурного, маскулинного/феминного в западноевропейских и российских воплощениях нации и этноса. ${ }^{66}$ Однако далеко не все основоположники и выразители славянских характерологий - в силу доминирования „мужского письма“ в науке, - видели и понимали данную дихотомию отчетливо. Она была отмечена в связи с интерпретацией расовых классификаций, отразившейся в антропологическом дискурсе первой трети и середины столетия: „коренное различие между племенами проводилось некоторыми гораздо дальше, чем между неграми и белыми. Многие немецкие историки и публицисты... видели в различии германцев и славян как бы различие половое и доказывали, что германцы представляют собой элемент мужеский, активный, а славяне - элемент женский, страдательный“.67 Это же отождествление этнической и гендерной дихотомий между собой отмечали и слависты - причем не только этнографы. На нее указывал, в частности, В. И. Ламанский, рассматривая западноевропейскую (главным образом немецкоязычную) славистическую историографию XVIII - первой половины XIX вв. ${ }^{68}$ Справедливости ради следует заметить, что данная интерпретация не была единственной, высказывались аналогичные гипотезы относительно других расовых (этнических) европейских групп. В частности, с женским началом сопрягались и романские народы, противопоставляемые 
германскому расовому типу как воплощению маскулинности. ${ }^{69}$ Поэтому наиболее известная в наше время классификация Ф. Ницше, делящая народы по „женскому“ и „мужскому“ типам, представляется лишь переосмыслением гораздо более ранних традиций немецкоязычной историософии.

C точки зрения западноевропейской традиции, таким образом, восточных и южных славянок объединяла принадлежность к „феминному“ этническому типу - следовательно, их рассмотрение должно было осуществляться либо в ракурсе „женственности в квадрате“, либо, напротив, им могли приписывать мужскую роль или качества. Российские авторы этнографических очерков - как научных, так и паранаучных, несмотря на прямо противоположную позицию и иные традиции славянских народоописаний, все же не могли полностью избежать влияния авторитетной для русских ученых немецкой историографии (в области этнографии и антропологии, в частности).

Все это оказало значительное влияние не только на стиль и способы описания и типизации женских образов „другого“ в текстах европейской культуры XIX века, но и обусловило длительное бытование определенных этнических стереотипов, особенно тех, которые касались нрава и внешности разных народов. В научно-популярных этнографических описаниях женщин и в записках о путешествиях этого периода - особенно первой половины столетия, очень сильно выражен уже упоминавшийся принцип изоморфизма (взаимосвязь внешности и характера), „прочитываемый“ в соответствии с основными категориями и оппозициями романтизма. Это определенные „стандарты“ в изображении так наз. „экзотических“ и роковых женщин, стереотипные характеристики „северных“, „южных“ (или „восточных“) обитательниц Европы. ${ }^{70}$ Для произведений русского романтизма характерна весьма примечательная - гендерная - двойственность в использовании стереотипа страстной („горячей“) роковой, морально раскрепощенной и зрелой (опытной) красавицы „южного типа“, противопоставляемой сдержанной („холодной“), добродетельной и зачастую целомудренной „северянке“.71 Эта оппозиция могла выражаться в различных дихотомиях этнического и регионального (петербурженка-русская/провинциалка, „южанка“ (цыганка, малороссиянка, гречанка и.т.п.); великороссиянка/малороссиянка) или сословного характера (великосветская дама / провинциальная барышня) и.т.п. Довольно отчетливым, как показывают исследования, было отождествление голубоглазой блондинки с „севером“, холодностью и добродетельностью, а черноглазой брюнетки с „югом“, пылкостью и свободолюбием. $^{72}$ „Женская красота, - пишет Буле, - виделась романтиками либо как северный, либо как южный тип, каждый из которых символизировал свои темпераментные парадигмы“.73

Перечень этнонациональных особенностей славян в российских этнографических описаниях был универсален - гендерных „подтипов“ в нем почти не наблюдалось. Наибольшие вариации заметны прежде всего в изображении антропологического облика и нравственных качеств. Одним из главных методов этнографического исследования родственных в этническом отношении народов был метод сравнения. Он применялся двояко для научного сопоставления этносов по известной программе-вопроснику, 
и для констатации субъективных, нерефлексируемых компаративистических суждений, присущих всякому дискурсу о Другом - когда наблюдатель или повествователь воспринимает и изначально фиксирует действительность в категориях „свой/чужой“, подчиняясь закономерности каузальной атрибуции. Неслучайно описание малорусов всегда осуществлялось через фиксацию кардинальных отличий их быта и нравов от великорусских, ${ }^{74}$ лейтмотивом очерков о крестьянстве Сербии становилось сходство образа жизни сербов и малорусов, а карелы, например, рассматривались как „промежуточная" группа между финнами-тавастами и русскими.

Следует упомянуть еще одну важную тенденцию, касающуюся описания женщин в связи с изображением этнического / национального идеала или этнического типа: это так наз. „этнизация феминного“ (термин О. Рябова), когда женские образы трактовались как воплощение этнического, находящегося в оппозиции к государственно-национальному. Женские образы и символы ассоциировались с традиционно-бытовыми крестьянскими формами культуры, в то время как мужские - с миром „города“, эпохи прогресса, модернизации и т.п., что оказало влияние на формы вербальной ${ }^{75}$ и визуальной ${ }^{76}$ репрезентации народов Европы в период конструирования наций.

\section{Польки}

Описания полек в этнографическом дискурсе эпохи можно считать наиболее противоречивыми. ${ }^{77}$ Эта неоднозначность была порождена методологической сложностью в выявлении польского этнического типа: согласно теории этничности того времени, „тип“ выявлялся через крестьянское сословие, в то время как и в польских научных и исторических самоописаниях, и в русской культуре предшествующего периода доминировал образ польки-дворянки, гармонично „встроенный“ в романтический идеал истинной патриотки. Польская крестьянка долгое время оставалась „неизвестна“ и польской, и русской литературе, так что даже обыденные представления, бесспорно оказывавшие влияние на восприятие этнического Другого, никак не могли сформировать необходимую почву. Напротив, сложившаяся традиция изображения „прекрасной и гордой“ польки в поэзии и беллетристике русского романтизма ${ }^{78}$ предоставляла готовые и клише, сложившиеся в сознании образованной элиты „естественным путем“. Красота, грация, гордость, ум, несравненное обаяние, - все эти особенности, по признанию многих наблюдателей, оказывают чарующее воздействие на мужчин, теряющих голову, подтверждая еще одно романтическое предубеждение об опасности и коварстве полек, делающих их своеобразным „орудием“ в патриотической борьбе поляков (представление о том, что именно женщина в условиях сурового политического противостояния является носителем польского патриотизма и готова жертвовать собой, сформировалось сначала в польском национальном автостереотипе). ${ }^{79}$ Довольно распространено было и мнение о том, что польская женщина рядом с русским мужчиной способна оказать на него как цивилизующее, смягчающее влияние (как, например, княгиня И. Лович - на Великого князя Константина Павловича), так и, напротив, по- 
губить, сделав его поклонником всего польского или католического - т. е. вылепить из него полонофила. Словосочетание „прекрасная и коварная“ в отношении польки можно оценивать как устойчивое языковое и литературное клише, бытующее и по сей день. Следует согласиться с исследователями-литературоведами в том, что на подобные представления оказал весьма сильное влияние образ польки („гордой полячки“) в русской литературе, причем не только романтической. ${ }^{80}$ Полька выступает как обольстительница, способная сделать из мужчины покорного раба, чтобы использовать его в интересах своего народа. Особенно интенсивные обвинения полек в „совращении“ русских в Западном крае обрушились после польского восстания 1863-64 гг. А. Востоков в „Наставлении своему сыну“ (1865) предостерегал: „берегись обольщения какою-либо полькою. В ремесле увлекать едва ли в целом мире найдутся искуснее обольстительных полячек. Для этой цели они неподражаемо искусно умеют притворяться, играть всякие роли. Не верь, русский, этим фокусам-покусам! Все это ловкая игра, все это обман и ложь. Вышедши замуж за русского, польки искусно успевают выведать все тайны, подметить его склонности, порывы, прихоти, слабости... Она будет шпионкою всех твоих действий,... будет передавать об этом сведения ксендзам и своим соотичам - тайным врагам России“.81

Красота полек воспевалась как в польской художественной литературе и поэзии, так и в заметках путешественников, - вовсе не только русских. „Польки причисляются к идеально красивым европейским женщинам“82 - констатирует Г. Плосс. Приведем довольно типичное мнение о польках А. фон Швейгер-Лерхенфельда, причем сделанное на основании сравнения с западно-европейским (романским) русским (восточно-славянским) типом, так как заметки эти сделаны автором во время его путешествия по Российской империи: „Полька всеми признана одним из европейских идеалов женской красоты. (...) в ней есть нечто ослепительное, особенно в спокойных классических чертах ее лица. Полька гораздо грациознее русской женщины, и изящество ее служит доказательством, что у нее больше вкуса, нежели у последней. В общем, она более нежного сложения, цвет лица прозрачнее и мягче, темные глаза выражают много живости, но в них нет выражения той чувственности, которую мы наблюдаем в голубых глазах северной русской женщины. Польская дама может служить образцом выдающейся расовой красоты, к которой присоединяется природная грация, вообще встречающаяся только у романских женщин“. ${ }^{83}$

Наиболее характерный перечень черт полек включает фиксацию их красоты и соответствующих им качеств „изысканности“, важных для коммуникации в определенных слоях общества. В русских описаниях обращает на себя внимание частотность упоминания „веселости“ полек, являющаяся отражением этнографического стереотипа поляка в научном дискурсе этой эпохи: ${ }^{84}$ „Польские женщины известны с древних времен своею миловидностью, нередко замечательной красотою. Они отличаются многими высокими качествами: остроумны, любезны, всегда веселы, находчивы, решительны, умеют ободрить мужей, они хорошие жены и матери, пользуются большим уважением, почетом и обыкновенно заправляют всеми делами в доме“.85 К. А. Скальковский относит к добродетелям полек их „твердый характер, 
деловитость и домовитость. Полька со средствами вдвое меньше против нашей русской женщины лучше будет вести свое хозяйство и лучше воспитывает своих детей (...) Легко командует своими мужьями“.86 В последнем утверждении нашло отражение бытующее в русской литературе второй половины столетия представление о том, что славянским женщинам (например, полькам, великороссиянкам и малороссиянкам, казачкам) присуща склонность к „управлению“ мужьями, которая, впрочем, не является врожденной, а вызвана слабохарактерностью и безответственностью супругов.

Достоинства и пороки народа, согласно господствовавшим представлениям, в равной степени находят выражение во всех группах - возрастных, социальных, гендерных. Поэтому кроме веселости, в описаниях полек фигурируют и все другие стереотипные определения поляков - такие как „господство сердца над разумом“, пылкость, эмоциональность, глубокая религиозность и „горячая любовь к родине“.87 „Поляки - народ храбрый, умный, легко воспламеняющийся, великодушный, красивый“88 - такое общее описание содержится в учебном пособии К. Кюна, в целом резко негативно оценивающего „бунтарскую“ деятельность польских патриотов. Восхищение грацией и миловидностью польских женщин в этом контексте можно трактовать как естественное внешнее выражение характерных особенностей польского национального характера в целом - открытости и эмоциональности. ${ }^{89}$ Любезность, остроумие, решительность интерпретировались как результат врожденных качеств (темперамента) и традиций рыцарской дворянской культуры. Поэтому подобные черты приписывались, как правило, дворянкам. ${ }^{90}$ Многие авторы, чтобы избежать возможных упреков, сознательно разделяли описания представителей разных сословий: „Польское дворянство резко отличается от массы народа. У дворян выразительные физиономии, волосы и глаза темные и часто орлиный нос. У женщин высших классов красивые и интересные лица; они высоки ростом, стройны, волосы у них очень темные, цвет лица нежный; вся их наружность и осанка дышат благородной гордостью“.91

В связи с этим можно отметить одну закономерность: описания польки-некрестьянки в этнографических очерках содержатся чаще всего в главах и подглавках, касающихся Варшавы и ее жителей. Таким локальным ограничением авторы, во-первых, стремятся нивелировать социальное противоречие - очевидное с точки зрения жанровой чистоты этнографического научного дискурса, и, во-вторых, имеют возможность выразить личные впечатления от польской столицы, жители которой чаще всего оказываются в сфере первоначального знакомства с краем „среднестатистического“ русского путешественника. Так, в географической хрестоматии 1860-х гг. Д. Д. Семенова говорится, что в Варшаве: „можно встретить много красивых женщин, которыми очень славится Варшава, но резкие черты лица и излишняя полнота часто портят польку (...) В обращении мужчин и женщин проглядывает врожденное благородство и уважение“.92

Фактически отождествляет варшавянок с польками, правда, „образованными“ К. А. Скальковский, хотя его критический взгляд фиксирует скорее негативные, нежели позитивные изменения типичного образа: „Польские женщины (...) в смысле типа варшавянки вырождаются. 
Польки по-прежнему отличаются умом и практической деловитостью, почему играют такую же роль в обществе, которая в других странах, даже во Франции, женщинам вовсе не принадлежит, но в наружном отношении (...) красота польских или варшавских женщин понижается“.93 Не разделяет его мнения В.О. Михневич. Описывая варшавских актрис, он утверждает: „Действительно, более очаровательного Олимпа по красоте богинь мне прежде не приходилось видеть (...) По справке все 'богини' оказались польками... Все они были довольно плохие актрисы и еще худшие певицы, но одна другой красивее и грациознее“.94

Своеобразным развитием мотива о темпераменте поляков, который просматривается как в утверждениях об их возбудимости и неумении владеть своими эмоциями (вплоть до экзальтированности - „не мешало бы польке немного меньше нервности“95), так и в упоминаниях их страстности, горячности, способности увлекаться, является оценка женской сексуальности. Авторы-мужчины интерпретируют ее в совершенно очевидных для читателя категориях чувственности и страстности, - в зависимости от позиции автора, оцениваемых негативно или позитивно. Тот же К. А. Скальковский утверждает, что „Польки менее всего сентиментальны; они, напротив, экзальтированны, строптивы и лукавы. Они холодны (...) недостаток полек - жеманство и аффектация“.96 Приписывание полякам вообще склонности к внешним эффектам и некой показной экзальтированности находит выражение в обвинении полек в постоянном желании блистать, производить внешнее впечатление („В их характере проявляется много стремления к блеску“: 97 „Польские дамы очень любят в своем наряде что-нибудь оригинальное, бросающееся в глаза“"98), что зачастую, по мнению авторов, приводит к цинизму и моральному падению: „Склонности полек к кокетству и желание их блистать и играть роль, тогда как денежные средства, особенно в чиновничьем мире, так скромны, делают то, что эти гордые и неприступные с виду пани только и мечтают, как бы попасть 'на утшимание' ('на содержание' - М. Л.)“.99

Еще одной вариацией темы польской эмоциональности является восходящий еще к XVII в. мотив сопоставления поляков с французами. Поляков издавна именовали „французами“ Восточной Европы или „северными французами“. Это сравнение активно используется в разного рода европейских характеристиках французов и поляков (француженок и полек в том числе ${ }^{100}$ ). Некоторые российские авторы, склонные к полонофобии, в 1860-80-е гг. неоднократно обращались к рассуждениям о взаимосвязи этой „французской“ живости нрава (горячего и одновременно легкомысленного) со „склонностью“ к антироссийским „бунтам“. Например, В. В. Макушев пишет о страстности, живости польского характера и той буйной веселости, за которую поляков справедливо именуют „северными французами“.101 Вторит ему и В. О. Михневич: „интеллигентная полька (...) ближе всего напоминает парижанку... В ней та же французская живость, та же кокетливая грация и то же женственное изящество“. ${ }^{102}$ Весьма комплиментарно сравнение поьских горожанок среднего достатка с француженками у Д. Д. Семенова: „Ни одна женщина в мире, исключая, конечно, француженки, не одевается так к лицу и так просто, как варшавянка. К сожалению, хорошенький наряд покупается днями тяжкой работы и составляет весь идеал, к которому она стремится о котором мечтает“.103 
Однако исследования показывают, что перед нами, скорее всего польский автостереотип, причем не чисто позитивного характера - здесь уместно вспомнить некоторые характеристики польского национального характера, содержащиеся в заметках самих поляков, служивших, в частности, в Петербурге и не „запятнавших“ своей репутации среди соотечественников-патриотов подозрениями в русофилии. Так, О. А. Пржецлавский в своих воспоминаниях ${ }^{104}$ рассуждал о „стихиях народного характера поляков“: „он есть смесь противоположных элементов: славянской беспечности, природной храбрости с французскою способностью (выделено мной - М. Л.) увлекаться первыми впечатлениями“. ${ }^{105}$ При этом автор считает поразительное сходство французского и польского темпераментов вовсе не лестным для славян, ${ }^{106}$ но „легкомысленные сарматы“ „делали все, чтобы удержаться на этой параллели. От своего образца они перенимали не только язык свободы, нравы, но и все умственное и политическое направление... Сходство с французами распространяется в Польше даже на низшие слои общества. Общественная жизнь в Варшаве, Вильне и других больших городах (...) есть сколок с жизни Парижа. Та же страсть к рассеянной уличной жизни, к публичных сборищам на открытом воздухе, ко всяким шумных увеселениям“. ${ }^{107}$ В этом же ключе следует рассматривать рассуждения о сходстве польского и французского национальных характеров русского по происхождению католика-эмигранта В. С. Печерина, ${ }^{108}$ которого нельзя отнести к типичным носителям русских этнокультурных стереотипов.

Впрочем, можно отметить также довольно явную взаимосвязь мотива польской - в том числе и женской - „веселости“ с любовью именно варшавян к праздничному времяпрепровождению, которая зачастую оценивается в мужском письме как позитивное качество полек и отличительная особенность досуга в варшавском дамском обществе. Умение варшавян отдыхать и развлекаться „удостоено“ неоднократных упоминаний в записках русских путешественников XVIII-XIX вв., став устойчивым стереотипом. ${ }^{109}$ В. Дедлов, как и другие, связывает эту „приятную“ для общения особенность с „женственностью“ истинной польки: „Она стройна и красива, она нравится и хочет нравится. Она, пока молода, имеет такой вид, точно задача ее существования - веселье во что бы то ни стало (...) Полька не знает скучным кавалеров. Она развеселит любого; она не знает скучных собраний: где она, там шутки и смех“. 110

Для сравнения обратимся к еще одному нерусскому описанию полек, включенному в географический труд Э. Реклю (который использовал как западноевропейские, польские и российские источники для своих обобщенных этнических характеристик народов): „Если первобытный тип сохранятся лучше всего у женщин, как это утверждают антропологи, то польки, развитые и образованные, ясно показывают своими качествами высокое достоинство расы, к которой они принадлежат: они не только отличаются изяществом манер, умом, постоянной веселостью, даром слова, но обладают также силой самоутверждения, мужеством, быстрой решимостью и живостью мысли; они хранят во всей чистоте и благородстве идеал нации“.111 Отметим корректное уточнение автором объекта описания - „развитые и образованные“ польки, что, вероятно, и побудило редакторов русского пе- 
ревода к обширному комментарию, касающемуся „типичности“ данного социального варианта этнического образа: „Эти стороны характера польской женщины и ее большее, чем где-либо, влияние на общественную жизнь и нравственность встречаются не только в среде образованных классов общества, но и простом народе; (...) в сословии сельских крестьян (...) явно обнаруживалось преобладание бойкой и живой инициативы женского ума“,112 и далее в качестве аргумента приведено мнение Н. В. Милютина.

Как видим, оценки Э. Реклю, хотя и позитивные, выдержаны в несколько более нейтральном тоне. Можно рассмотреть в связи с этим цитату из довольно популярного в свое время путешествия В. Дедлова, фрагменты которого очень часто включались в этнографические популярные издания „для детей“ и „для народа“.113 Дедлов цитирует характеристику Реклю, но по ходу несколько видоизменяет ее: „Вероятно, поляки привлекательны для женщин в такой же мере, как польки для нашего брата мужчин, но полька благородней. Вот что говорит о польках Реклю в своей знаменитой географии: если антропологи правы, что первоначальный тип полнее сохраняется в женщине, тогда развитая и образованная полька своими редкими качествами обнаруживает высокое достоинство родной расы: она не только любезна, остроумна, всегда весела и разговорчива, но и преданна, мужественна, решительна и здравомысляща. К сожалению, таким идеалом является полька развитая и образованная, великая редкость в стране“.114 Как видим, он дважды повторяет уточнение „развитая и образованная“, подчеркивая тем самым социальную ограниченность позитивных черт женского образа.

Вернемся к описанию Михневичем варшавянок. Несмотря на избранный автором жанр путевых заметок и живописные экскурсы, его изображение полек выполнено с явной опорой на известные научно-этнографические описания и антропологические классификации - это заметно в лексике, в последовательности изложения. Его попытка выявить гендерные антропологические подтипы свидетельствует о том, что он действительно был знаком с современной научной литературой и стремился представить „максимально объективную“ и научно-обоснованную картину: „Мне бросилось тогда же в глаза подтвержденное потом другими наблюдениями разнообразие типов варшавянки, которые (...) можно разгруппировать на два расовых. Один тип - чисто сарматский, несколько аналогичный кавказским - восточным: черные волнистые волосы, большие черные, огненные глаза, продолговатый овал лица, тонкие черты, тонкий небольшой орлиный нос и стройное, сухощавое тело. Другой тип - контраст первому - тип чисто славянский: русые волосы, голубые или серые глаза с 'соболиными бровями' и чудесными ресницами, нежный цвет лица не совсем правильного, с шаловливым, чуть вздернутым носом, прекрасно-развитый торс и ослепительная белизна кожи. (...) В эти два генерические типа, без сомнения, укладывается множество разновидностей“.115 Таким образом, противопоставляя кавказский расовый тип славянскому, он одновременно выделяет два субэтнических антропологических подтипа, заметных только в женской ипостаси. Такой „научный“ подход также предоставляет ему основания для объяснения причин польской женской притягательности: „не в этом ли (...) - восклицает автор, - смешении противоречащих качеств и недостатков, делаю- 
щих самую убогую в нравственном и умственном отношении польку чем-то загадочным?“116 Однако К. А. Скальковский довольно строго „комментирует“ этот вывод Михневича, усматривая в этой „этнической классификации“ отчетливую социальную подоплеку, которая в некотором смысле является подтверждением известной вариации сарматской теории - так наз. „теории завоевания“: „Первый тип встречается чаще у аристократок, второй - в массе народа. В первом типе давно находили сходство с восточным... второй тип приближается к славянскому; (...) (он - М. Л.) демократический, ибо подгулявшие носы всегда отличают отсутствие в женщинах породы“.117

\section{Малороссиянки}

В российских репрезентациях разного рода - в том числе и визуальных - в XIX в. малорусы (малороссы) представали как смуглолицые и румяные, черноглазые и черноволосые, статные, дородные, с обликом, „исполненным жизненной энергии и силы““ ${ }^{118}$ Аналогичные „типы“ малороссов фигурировали в качестве персонажей художественной „малороссийской“ литературы „народного“, этнографического характера (украинско- и русскоязычной) - особенно многочисленной в 1830-60-е гг. ${ }^{119}$ В них женские образы всегда занимали значимое место, способствуя формированию украинского этностереотипа, в том числе и гендерного, ${ }^{120}$ в русском сознании.

Этнографические очерки второй половины XIX в. часто включали описания малороссиянок (именуемых „хохлушками“ - в отличие от „казачек“), напрямую заимствованные из беллетристики или составленные на основании литературных произведений (прежде всего Н. Гоголя, а также повестей и пьес таких малороссийских авторов как П. Гулак-Артемовский, Е. Гребенка, Г. Квитка-Основьяненко - в которых отчетливо проявлялась сатирическо-юмористическая тональность). Если в начале XIX в. описания „малороссийских красавиц“ составлялись без учета их сословной принадлежности - в их число попадали социально „неопределенные“ представительницы провинциального общества („Женщины здесь очень миловидны, почти все с томными и вместе пламенными глазами, в которых чувствительность души и сердца так ясно изображается. Природа положила на лицах их печать любви и нежности“, 121 - писал князь П. И. Шаликов в 1803 г.), то во второй половине столетия эталон женского этнического типа - в строгом соответствии с этнографическими установками - формировался исключительно на примере низших социальных слоев.

Следует отметить, что образ „простого малороссиянина“ - „хохла“ функционировал в российских этнографических описаниях на протяжении всего XIX в. и комплекс внешних примет, существовавших до научноантропологической реконструкции, вовсе не является плодом одной лишь украинской романтической литературы. ${ }^{122}$ Определяющую роль играло характерное для украинофильских деятелей, начиная еще с Н. И. Костомарова и П. А. Кулиша, стремление „описать через отличия“ - то есть обозначить своеобразие малоруса и великоруса (в том числе и антропологическое ${ }^{123}$ и „нравственное“) посредством их сравнения, в то время как аналогичные по- 
иски идеального великоруса, как правило, оказывались безуспешными - в связи с большим количеством вариаций типа. ${ }^{124}$

Любопытно, что метод такого сопоставления в описании „русских“ Российской империи (т.е. восточнославянских этнических групп) отличает и западноевропейские очерки. Можно предположить, что это связано концепцией единого русского народа - в этом случае иностранный наблюдатель сам должен был установить очевидные различия между малорусами и великорусами, интерпретируя их как региональные, а не этнические, используя при этом наиболее удобное объяснение несходства „северной“ и „южной“ разновидностей „русского этноса“, и, кроме того, включая сопоставление с поляками. „Малорусская женщина - гораздо более живого и горячего темперамента, нежели ее северная сестра (великороссиянка - М. Л.) и по внешности более напоминает собой женщин южного типа. Оно большого роста, стройна, с темными, выразительными глазами и темными волосами... Формы тела так стройны и изящны, что невольно напоминают собою польских женщин.... горячее чувство или пылкая страсть (...) часто овладевает душой южно-русской женщины“, 125 - пишет А. фон Швейгер-Лерхенфельд.

Согласно научным взглядам эпохи, внешние черты, как уже говорилось, всегда отражают свойства народного нрава и наоборот, что позволяет по визуальному наблюдению делать выводы о национальных качествах народов. Поэтому признаки красоты и „довольства“, которые можно считать типичными в этнографических очерках о малорусах, являются важными показателями их благополучия и добродетельности. Представителей малорусского племени отличает также физическая выносливость и „крепость“. Малороссиянкам приписывается красота, живость и веселость (последнее свойство отличает их от мужчин, которые, по мнению наблюдателей, угрюмы, неразговорчивы и склонны к хандре - стереотипные качества нрава малорусского крестьянина), ${ }^{126}$ а также бесспорная „статность и грациозность“. ${ }^{27}$ При этом авторы подчеркивают, что женская „живость не переходит в бабность и нескромность“. 128

Малороссиянки - так же, как и польки, описываются в категориях красоты и физической сексуальной привлекательности - в первую очередь в связи с внешней „яркостью“, здоровьем, телесной „пышностью“, ассоциируемой с „востоком“. О женской красоте „хохлушек“ упоминается, например, в „Живописной России“. Автор очерка об Украине при этом подчеркивает, что малороссийская женщина отличается от другой русской красавицы-сестры: „Украинка совсем не похожа на свою великорусскую сестру - лебедушку белую“. ${ }^{129}$ Это несходство связано прежде всего представлениями об отличительных особенностях жителей „юга“, в том числе и Российского: невысокий рост, телесная „крепость“, витальность, темный цвет глаз и волос, выразительность черт лица, стройность и гибкость стана. Но эти приметы пылкого темперамента и живости „природного склада“ казались в то же время признаками чувственности, что могло быть почвой для „злоупотреблений“ в нравственной сфере. Отсюда - настойчивое стремление авторов оградить читателей от поспешных выводов. Так, некоторые авторы вступаются за репутацию малороссийских девушек, давая „этнографическое“ объяснение ложному мнению: „об украинских девушках сложилось убеждение, что они 
будто бы рано лишаются целомудренности. Но это - ошибка. Причиной ложного мнения о малорусской девушке является обычай, не существующих у великорусов - это 'вечорницы'“. 130

Еще одним характерным примером может служить следующее заключение, в котором „хохлушки“ сравниваются с польками: „Малороссиянки одарены всею тою прелестью обхождения, которую так прославляют в польках, но превосходят их в искренности и прямодушии, чужды их навязчивого кокетства и никогда не теряют власти над собой даже в минуты самого страстного увлечения“" 131 В этой „двойной“ оценке славянских женских типов отчетливо выражены не столько эстетические или гендерные предпочтения конкретного автора, сколько проявлено стремление указать на большую этническую близость (и потому „безопасность“) восточной славянки „южного типа“. Некоторые другие особенности характера малороссиянок (верховенство над мужчинами, решительность и др.) связываются с более высоким (вплоть до лидерства), нежели у великорусов, правовым и семейным статусом женщины.

Образ малороссиянки в этнографических описаниях Российской империи в целом можно определить как положительный, особенностью этих гендерно-этнических характеристик является, на наш взгляд, отсутствие прямых описаний. Большая часть довольно скупой, по сравнению, например, с очерками великорусской или польской женщины, информации дается на фоне двойного сравнения. В подавляющем большинстве „русских“ (восточнославянских) репрезентаций доминирует сравнительный способ изложения - в форме перечня сходств и различий двух или трех этносов между собой. В этом случае в центре внимания оказывается внешность женщин и ее положение в семье и обществе. Авторы утверждают, что малороссиянки более свободны („менее угнетаемы“), чем великороссиянки, пользуются большими правами и авторитетом, принимают заметное участие в общественной и национальной жизни, а также редко оказываются в роли забитых и беспомощных „рабынь“ мужа. ${ }^{132}$

Второе сопоставление присуще только малороссийским очеркам: характер, образ жизни и способности женщин поданы как отличающие их от нрава, темперамента и видов деятельности мужчин. Этим сравнением, которое оказывается не в пользу мужчин-малороссов, пронизано изображение этнического нрава в очерке П. П. Чубинского и в главах „Живописной России“. При этом речь идет не только о гендерных вариациях этнического типа, но, в сущности, о противопоставлении мужского и женского „психотипов“ и характеров. Несмотря на сентиментальность и „задумчивость“ обоих, женщину легче довести до слез, она более „чувствительна“ и жалостлива. ${ }^{133}$ Кроме уже упоминаемой веселости (противопоставляемой „хохлацкой угрюмости“), малороссиянке приписывается и другая черта, оцениваемая как признак „духовной силы“: она еще более, чем мужчина, „упарта“ и оттого менее подвержена упадку духа - не впадая в уныние, столь типичное для малоруса, она одна выносит все выпадающие на долю семьи тяготы, являясь не только главой семьи, но и опорой всего сообщества (во время войн и бедствий). ${ }^{134}$ Женщины малороссийского племени, в отличие от мужчин, в полной мере наделены способностями и желанием вести торговлю, а по- 
тому у них развита сметливость и предприимчивость, полностью отсутствующая в мужском типе. ${ }^{135}$

Гораздо более негативно оценивается различие между мужским и женским типами в области морали: П. П. Чубинский утверждает однозначно, что „малорусская женщина положительно стоит выше мужчины во всех отношениях“. ${ }^{136}$ Мужчина ленив и медлителен, ${ }^{137}$ женщина работяща и „быстра“: „малорусская женщина работает вдвое больше мужчины“.138 Часто упоминаемое чувство юмора - как типичная черта малорусов - в женском варианте проявляется более деликатно: „тон женской речи большей частью добродушно-наивный. Шутка женщины не резка, и в речи ее, как и на лице, всегда отыщется оттенок грусти“.139

Наиболее характерно чертой, отличающей описание полек от очерков о малороссиянках, является, безусловно, отчетливо выраженные сословная (в первом случае) и гендерная (во втором) типизация этнических образов.

\section{Сербки}

Описания сербок не включены в народоописания этносов Российской империи, и потому содержатся главным образом в путевых заметках, мемуapax и репортажах из Сербии, однако в 1890-1900-е годы они постепенно складываются в цельные научные очерки, создаваемые по уже разработанному в русской этнографии образцу.

Обратимся сначала к западноевропейским характеристикам. Например, Францу Шереру сербки очень нравятся: „особенно в городах Сербии встречаются часто очень изящные женские фигуры; между ними попадаются лица с самыми тонкими чертами и часто действительно поразительной красоты. Живые темные глаза, темные волосы, удивительно бледный и притом с южным оттенком цвет лица, щеки, подернутые нежным румянцем, придают такому лицу нечто необыкновенно благородное; если ко всему этому представить себе безупречную фигуру такой красавицы, одетую в национальный костюм, весьма выгодно выделяющий мягкими линиями стройные формы тела, то получается прелестная картина“. ${ }^{140}$ Не столь вдохновлен женской красотой сербского этнического типа Э. Реклю, безусловно признающий мужскую привлекательность сербов; женщины в его описании, напротив, „не обладают красотою, но имеют благородную осанку и их полувосточный костюм отличается удивительной гармонией цвета“.141 Сдержан в оценках А. фон Швейгер-Лерхенфельд: „Несмотря на свое приниженное положение в семействе, сербка весела и энергична, очень любит пение... Относительно внешности сербки можно заметить, что истинные красавицы между ними не слишком часты. В городах, правда, встречаются иногда безупречно прелестные, правильные лица, но (...) в деревне они грубее и резче“. ${ }^{142}$ Наибольшего восхищения удостоились „прекрасные карие глаза сербок“ и их „прекрасные темные волосы“, фигура же произвела впечатление „плотной“ и потому недостаточно подвижной и грациозной. ${ }^{143}$

Российские характеристики сербок - независимо от позиций и взглядов авторов - отличает некоторая дистанцированность наблюдателей 
от объекта описания. Неверно было бы определять эту дистанцию как обусловленную „чуждостью“ культуры - напротив, в очерках постоянно подчеркивается племенное и конфессиональное родство, а также признание в явной симпатии и духовной близости сербам (которые, вероятно, следует объяснять славянофильскими идеями и мотивами солидарности с сербами во время русско-турецкой войны). ${ }^{144}$ Однако некая отстраненность в нравоописаниях в целом все-таки присутствует.

Как и во всех других характеристиках гендерных вариантов этнического типа, наиболее пристальное внимание привлекает внешний облик сербок, с непременными оценками женской привлекательности. Одним из наиболее квалифицированных в этнографическом отношении специалистов по славяно-балканскому региону был, безусловно, П. А. Ровинский. Но и его детальный антропологический очерк не лишен мужской пристрастности: „В Белграде много красивых женщин, в особенности девушек. Вот вам тип: правильный профиль, тонкие черты лица, большие глаза - черные или темно-голубые, спокойно глядящие через бархатные ресницы из-под тонких смежных черных бровей; лицо белое как мрамор, и редко увидишь на нем игру румянца; как мрамор, оно холодно и неподвижно. (...) Вечно потупленный взгляд и какая-то неподвижность в лице молодой сербской женщины как будто скрывает тайну ее мыслей и желаний, и отнимает у него жизнь и выражение. Вся она тонкая и стройная, но грудь впалая, в движении неловкость и вялость. Такая красота проходит очень рано: вскоре после замужества“. ${ }^{45}$ „Карие глаза и черные волосы, - разделяет такое мнение К. А. Скальковский, - их красят, но плотная и неловкая фигура и недовольно белая кожа их портит; они не отличаются оживлением..."146

Столь приятная мужскому взгляду русских наблюдателей польская и малороссийская „живость“ и „бойкость“ в Сербии не находит воплощения в женском облике - он кажется как бы „скованным“, „зажатым“ - объясняемой жесткими (вероятно, под влиянием строгой патриархальности и мусульманства) нормами поведения в обществе чужих мужчин. Красота сербок бесспорна. ${ }^{147}$ Вторит П. А. Ровинскому еще один другой русский путешественник: „Женщины красивы, но красота эта представляет что-то слишком однообразное и неоживленное; слишком мало игры физиономии на женских лицах“. ${ }^{48}$ Грации лишены и движения сербок: „Говорят, что красивыми женщинами Сербия значительно богаче, чем соседняя Черногория, но зато они, подобно сербам, лишены той легкости и эластичности движений, которые свойственны черногорке. Относительно своих наружных преимуществ сербка занимает среднее положение между северной славянкой, романкой и гречанкой“. 149

Такое восприятие легко объяснить, обратившись к центральному и признаваемому наукой той эпохи принципу изоморфности в изображении „физиогномических“ отличий этнического типа и образа жизни народа. Наиболее часто констатируемой особенностью положения сербской женщины в общине (задруге) и обществе является ее полная зависимость от мужчины, воспитываемая в ней покорность. Несмотря на общие для мужчин и женщин такие свойства национального характера как мужество и выдержка, в семейной и общинной жизни женщины эти качества остаются 
невостребованными - она не имеет права голоса, а всякое проявление каких бы то ни было чувств к ней со стороны мужчины подвергается осуждению и насмешкам. „Нравы“ сербов в этом отношении оказываются более схожи с кавказскими и мусульманскими народами России, а облик сербской женщины напоминает мусульманско-турецкий эталон прекрасной, но недоступной собственности мужчины-хозяина. Ее главный недостаток - всякое общение для нее полностью исключено, а потому отсутствуют открытые эмоции; самовыражение и какое-либо проявление чувств и мнений исключается. Довольно жесткий и циничный в оценках женских этнических типов К. А. Скальковский отмечает, что в связи с закрытостью и фактически запретом на коммуникацию вне семьи сербки (Далмации) ведут „жизнь живых мертвецов, которые влачат чопорное существование“.150

Как уже указывалось, наиболее эмоциональные оценки такого положения принадлежат авторам-женщинам. Е. Н. Водовозова и Э. К. Пименова, например, употребляют определения „рабская покорность и униженность“, „бесправие“. 151 „Пожалуй, ни у одного европейского народа женщина не занимает такого унизительного положения, как в Сербии“, 152 - убеждена Э. К. Пименова. Эта архаично-патриархальное отношение к женщинам и накладывает неизгладимую печать приниженности на ее красоту.

Таким образом, гендерные вариации славянских типов трех разных групп, представленные в российских научных этнических репрезентациях второй половины XIX века, нельзя трактовать как прямое отражение особенностей русского восприятия. Они выстраиваются в соответствии с европейскими традициями изображения этнической специфики, что проявляется, в частности, в некоторых европоцентристских оценках, в усвоенной просвещенческо-романтической дихотомии славянской и германской стихий и классификации этнокультурных типов в категориях севера/юга, запада/ востока, цивилизации/дикости и т.д., а также - в общих установках мужского этнографического нарратива. Но в российских этнографических описаниях славянских народов находит выражение собственно национальная специфика восприятия и описания Других. Она заметна в воздействии женских образов и типов художественной литературы вообще и литературы так наз. „этнографизма“ в частности, в бытовании русских этнокультурных стереотипов более раннего времени.

При этом их авторы активно используют общеевропейские установки в изображении женских антропологических типов в категориях красоты/безобразия. Трудно судить о „расовой“ (в современном смысле слова) предубежденности российских наблюдателей, так как мы рассматривали только восприятие ими славян, поэтому следует предполагать, что общая позитивность этого образа вполне может быть обусловлена не этническим, но „Племенным“ центризмом (фаворитизмом) позиции. Наконец, конкретные „параметры“ описания внешности и нравственных качеств демонстрируют присущие „дофеминистической эпохе“ гендерные предубеждения авторов с одновременным признанием взаимосвязи внешнего облика с положением женщины в социуме. Кроме того, очевидно, что они содержат в себе многие архаические черты русских этностереотипных визуальных и вербальных репрезентаций в целом, выполненных в жанре сравнительных 
народоописаний: условность изображения, акцент на сопоставление, лаконичность формул и др.

В триаде рассмотренных гендерных образов, репрезентирующих этнические типы западных, восточных и южных славянок, обнаруживается не только их своеобразная иерархия, обусловленная, во-первых, общеэтническим характеристикам этих народов, во-вторых, продиктованная степенью этнокультурной близости. Эта разница в дистанции, на наш взгляд, может быть объяснена в контексте так наз. „колониального“ взгляда наблюдателя и описателя-мужчины. Наиболее позитивными оценками наделены польки - как представительницы западноевропейской культуры, сравниваемые с француженками. Но они и самые далекие на шкале оппозиции свой / чужой. Неслучайно им приписывается коварство и неискренность. Напротив, самыми „близкими“, „своими“ - по вполне очевидным причинам этнокультурного родства - для русских наблюдателей оказываются малороссиянки. Их внешний облик, с одной стороны, воспринимается авторами этнографических очерков как эстетически, эмоционально и сексуально более привлекательный (они наделены приметами „южных“ женщин), однако постоянно акцентируемые высокие нравственные качества, особенно заметные в сравнении с недостатками мужской этнической ипостаси малороссиянина, выступают доказательством их „безопасности“ и потенциальной эмоциональной, душевной близости и надежности. Наименее отчетлив образ сербки. Ее физическая красота, некоторое сходство со стереотипным изображением „восточных дев“ (турчанок, „одалисок“153), должно было бы привести к некоторой общности в оценках и описаниях их нрава. Однако этого не произошло. Сербки изображаются как чрезмерно закрытые (вплоть до забитости) „славянские рабыни“ мужчин, что не позволяет отождествить их со стереотипным образом восточных женщин, доминировавшим в западноевропейском расовом дискурсе эпохи. В их характеристиках прочитывается гораздо более сходства со знакомой русским наблюдателем кавказско-мусульманской культурой, недоступность и нравственная чистота женщин в которой не ставится под сомнение. Это - иной „восток“ и несколько иной гендерный ориентализм. Вместе с тем на восприятие и описание русскими авторами этнических типов их женском воплощении оказали влияние не декларируемые, но просматривающиеся сословные различия: полька всегда в сословно-культурном и образовательном отношении ближе, нежели крестьянка-сербка. Хотя многие наблюдатели отдают себе отчет в том, что в Польше существует - так же, как и в России, - огромная дистанция между дворянским и крестьянским женскими типами красоты и характера.

Таким образом, можно констатировать, что в российских народоописаниях второй половины XIX в. гендерные образы избранных славянских народов подчиняются общим принципам их характерологии. Изображение внешнего облика женщин ограничивается кругом оценочных суждений, касающихся „красоты“ лица и телодвижений, которые формируются в дискурсе так наз. „мужского письма“ (исключение составляют сочинения женщин), играя лишь дополнительную роль в репрезентации этничности. По-прежнему заметны архаические элементы нравоописаний - такие как 
изоморфизм внешних признаков и нравственных свойств, а также принцип пространственно-географической обусловленности этих элементов национального нрава / характера. При этом последний, климатический, фактор проявляется в двух видах: как природно-хозяйственные основания и как символически-образный контекст рассуждений. Славянские женщины в соответствии с романтическими установками выступают, с одной стороны, как носительницы европейского начала, противопоставленного германской стихии, а, с другой, подвергаются дифференциации на основании выделения „южных“ и „северных“ типов, причем в различных областях сопоставления эти предписанные им образы могут варьироваться. В целом не вызывает сомнений факт, что данные описания в гораздо большей степени отражают стереотипы и бытующие в европейском сознании суждения о Других народах Европы, нежели сугубо русский взгляд или национальное восприятие этнокультурных особенностей полек, сербок и малороссиянок. Они продиктованы общеевропейскими и романтическими русскими традициями этнических репрезентаций-нарративов.

\section{Примечания \\ (Endnotes)}

1 Мыльников А. С. Картина славянского мира: взгляд из Восточной Европы. Этногенетические легенды, догадки, протогипотезы XVI - начала XVIII века. СПб., 1996; Он же. Картина славянского мира: взгляд из Восточной Европы. Представления об этнической номинации и этничности XVI - начала XVIII века. СПб., 1999.

2 Мыльников А. С. Картина славянского мира: взгляд из Восточной Европы. Представления об этнической номинации и этничности. С. 149-179.

3 Вуль $\varnothing$ В. Изобретая Восточную Европу: карта цивилизации в сознании людей Просвещения. М., 2003.

4 Boemus I. Omnium gentium mores, leges et ritus. 1520; пер. на англ. яз: Boетus I. The Fardles of Facions... of J. Boemus by W. Warerman. Edinburgh, 1611; Barclay I. Icon animorum. London, 1614; пер на англ. яз.: Barclay J. The Mirror of Minds. London, 1634; Besoldus Ch. De natura populorum et de linguarum ortu atque immutatione. Tubingen, 1619 и др.

5 См., например: Байбурин А. К. Некоторые вопросы этнографического изучения поведения // Этнические стереотипы поведения. Л., 1985. С. 7-18; Чеснов Я. $B$. Этнический образ // Этнознаковые функции культуры. М., 1991. С. 58-85; Соколовский C. В. Этнографические исследования: идеал и действительность // Этнографическое обозрение. 1993. № 2-3; Соколовский С. В. Этнография как жанр и как власть // Этнометодология: проблемы, подходы, концепции. Вып. 2. М., 1995. С. 133-147; Куприянов П. С. Представления о народах у российских путешественников начала XIX в. // Этнографическое обозрение. 2004. № 2. С. 21-38 и др.

6 Саид Э. В. Ориентализм. Западные концепции Востока. СПб., 2006; Вуль Изобретая Восточную Европу: карта цивилизации в сознании людей Просвещения. М., 2003.

7 Лескинен М. В. Поляки и финны в российской науке второй половины XIX в.: 
„Другой“ сквозь призму идентичности. М., 2010. С. 102-113.

8 Подробнее об этом: Лескинен М. В. От „натуры“ к „гению“: традиции нравоописания европейских народов XVI-XVIII вв. // Текст славянской культуры. К юбилею Людмилы Александровны Софроновой. М., 2011. С. 431-448.

9 Barclay J. The Mirror of Minds. Ch. 3.

10 Мосс M. Техники тела // Мосс М. Общества. Обмен. Личность. Труды по социальной антропологии. М., 1996; Бурдье П. Начала. М., 1994.

11 Халдеева Н. И. Антропоэстетика. Опыт антропологических исследований. М., 2004. C. 5-6.

12 Marwich A. Beauty in history. 1988; Липовецкий Ж. Третья женщина. СПб., 2003. Ч. 2. Гл. 1.

13 Fulemile A. Dress and Image: Visualizing Ethnicity in European Popular Graphics Some Remarks on the Antecedents of Ethnic Caricature // Images of the Other in Ethnic Caricatures of Central and Eastern Europe/ Ed. by D. Demski and K. BaranieckaOlszewska. Warsaw, 2010. P. 30-41.

14 Leerssen J. The poetics and anthropology of national character. 1500-2000 // Imagology. The cultural construction and literary representation of national characters. A critical survey edited by M. Beller and J. Leerssen. Studia Imagologica. Vol. 13. Amsterdam, NY, 2007. Р. 63-75; Вишленкова Е. А. Визуальная антропология империи, или „увидеть русского дано не каждому“. Препринт WP6/2008/04. М., 2008. Гл. 1-2.

15 „Краткое описание пребывающих в Европе народов и их свойств“ опубликовано в: Kopelew L. Fremden bilder in Geschichte und Gegenwart // Russen ind Russland aus deutschen Sicht 9-17. Mыnchen, 1985). Текст и анализ памятника на рус. яз. см.: Мыльников А. С. Картина славянского мира: взгляд из Восточной Европы. Представления об этнической номинации и этничности. С. 176-179. Детальный разбор таблицы представлен в работах: Stanzel F. K.: Europдеr. Ein imagologischer Essay. Universitдtsverlag C. Winter, Heidelberg, 1997. Первая известная „таблица“ народов помещена в сочинении доминиканского монаха Иоанна Зана (Zahn J. Specula physico-mathematico-historica notabilium ac mirabilium sciendarum Vol. 1-3. Nurnberg, 1699). Подр. о нем: Leerssen J. The poetics and anthropology of national character. 1500-2000 // Imagology. P. 68-69.

16 Fulemile A. Op. cit. P. 45-47.

17 Вишленкова Е. Визуальное народоведение империи, или „увидеть русского дано не каждому“. М., 2011. С. 139-144; Лескинен М. В. Поляки и финны. C. 102-104.

18 Курганов Н. Российская универсальная грамматика, или Всеобщее письмословие, предлагающее легчайший способ основательного учения русскому языку, с седьмью присовокуплениями разных учебных, полезнозабавных вещей. СПб., 1769.

19 Исследователями источников, используемых Н. Г. Кургановым (он не скрывал своих прежде всего компиляторских задач) обнаружено главное сочинение, из которого составитель непосредственно позаимствовал таблицу свойств народов - многократно переиздававшаяся на протяжении полутора веков „Полная грамматика французского языка“ Ж.-Р. де Пеплие (точная дата неизвестна, незадолго до 1689 г.) (Рак В. Д. „Присовокупление второе“ в „Письмовнике“ Н.Г. Курганова // XVIII век. Сб. 12. Радищев и литература 
его времени. СПб., 1977. С. 209). Можно с высокой степенью уверенности предположить, что в грамматику оно попало, в свою очередь, как обработка или переделка по образцу уже упомянутой „доски народов“ (Volkertafel) „Краткого описания пребывающих в Европе народов и их свойств“.

20 Здесь и далее цитирование по изданию: Курганов Н. Присовокупление II // Курганов Н. Письмовник, содержащий в себе науку российский язык. М., 1837. С. 353.

21 Вишленкова Е. Визуальное народоведение империи. С. 107-117.

22 Лескинен М. В. Поляки и финны. С. 37-48.

23 Подробнее об этом: Там же. Гл. 1.

24 Там же. С. 116-118. Истории интерпретации расовой теории в российской физической антропологии XIX века посвящена монография: Могильнер М. Homo Imperii. История физической антропологии в России. М., 2008, однако некоторые заключения автора представляются нам не достаточно убедительными. Среди новых публикаций о содержании понятия „раса“ в российской науке XIX в. следует упомянуть также: Тольц $B$. Дискурсы о расе: имперская Россия и Запад в сравнении // „Понятия о России“. К исторической семантике имперского периода. М., 2012. С. 145-193; Холл К. „Расовые признаки коренятся глубже в природе человеческого организма“: неуловимое понятие расы в Российской империи // Там же. С. 194-258.

25 Однако многие ученые полагали, что заключения, сделанные на основании количественных методов и „интуитивных“ способов, совпадают (подр. об этом: Лескинен М. В. Поляки и финны. С. 109-111).

26 В частности: Программа для этнографического описания губерний Киевского учебного округа, составленная по поручению Комиссии, высочайше утвержденная при Университете святого Владимира, действительными членами Князем В. Д. Добижею и (по языку) А. А. Метлинским. Киев, 1854; Известия ОЛЕАЭ при Императорском Московском Университете. T. XXVII. Антропологическая выставка. T. I. М., 1878; Программа для собирания этнографических сведений, составленная при Этнографическом Отделении ОЛЕАЭ. М., 1887; Программа для собирания сведений по этнографии. Императорское русское географическое общество // Живая старина. 1890. № 1. Раздел II. C. XLVII-LII.

27 Например: Шульгин В. Историческое исследование о состоянии женщин в России до Петра Великого. Киев, 1850; Забелин И. В. Древняя русская литература. Женщина по понятиям старинных книжников // Русский вестник. 1857. № 9; Мосолов A. Русское воспитание в женских типах нашей литературы // Светоч. 1860. № 3; Макушев В. Сказания иностранцев о быте и нравах славян. СПб., 1861; Добряков А. Русская женщина в домонгольский период. Историческое исследование. СПб., 1864; Ровинский П. А. Из истории славянских женщин // Неделя. 1869; Веселовский А. Из истории развития личности. Женщина и старинные теории любви (1872). СПб., 1912; Мниховский А. Женственность. Киев, 1885; Котляревский А. А. Женская красота по понятиям славянских и германских племен // Котляревский А. А. Собрание сочинений в 6-ти тт. Т. 4. СПб., 1895. С. 693-701; Шашков С. С. Исторические судьбы женщины // Шашков С.С. Собр. соч. в 2-х тт. СПб., 1898. Т. 1; Астафьев П.Е. Психологический мир женщины, его особенности, превосходство и недостатки. М., 1899 и др. Несколько особняком в этом ряду стоит весьма своеобразное сочинение Скальковского, получившего большой резонанс в 
русском обществе из-за жестко-ироничной позиции автора по „женскому вопросу“: Скальковский К. А. О женщинах: мысли старые и новые. СПб., 1886.

28 Тодоров Ц. Раса и расизм // Новое литературное обозрение. 1998. № 34. С. 8.

29 Аргументация в: Лескинен М. В. Поляки и финны. Гл. 9.

30 Например, в: Богданов А. П. Антропологическая физиогномика // Русская расовая теория до 1917 г. Сборник оригинальных работ русских классиков / Под ред. В. Б. Авдеева. В 2-х вып. Вып. 1. М., 2004. С. 139-141; Котляревский А. А. Указ. соч.

31 Красота // Мужики и бабы. Мужское и женское в русской традиционной культуре. Иллюстрированная энциклопедия. СПб., 2005. С. 279, 280.

32 Семенова-Тян-Шанская О. Жизнь „Ивана“. Очерки быта крестьян одной из черноземных губерний // Записки ИРГО по отделению этнографии. Т. 39. СПб., 1914; Семенов С. Т. Двадцать пять лет в деревне. Петроград, 1915. С. 40-43; Ожегов М. И. Характеристика своего народа. По вопросам Программы исследований литературы для народа Н. А. Рубакина // Чтение в дореволюционной России. Вып. 1. М., 1992. С. 135-142.

33 Репрезентативной квинтэссенцией наиболее типичных, но не претендующих на научность, суждений по этому вопросу, представляет собой упомянутая книга Скальковского (Скальковский К. А. О женщинах...).

34 Подробная библиография проблемы и некоторые обобщения историографических позиций даны в: Могильнер М. Указ. соч. С. 6-18; Knight N. Ethnicity, Nationalism and the Masses: Narodnost and Modernity in Imperial Russia // Russian Modernity: Politics, Knowledge, Practices. NY, 2000. P. 58.

35 Тодоров Ц. Указ. соч. С. 8-9; Соколовский С. В. Расизм, расиализм и социальные науки в России // Расизм в языке социальных наук. СПб., 2002. С. 31-44.

36 Слёзкин Ю. Арктические зеркала. Россия и малые народы Севера. М., 2008. Гл. 3-4.

37 Подробно об этом: Лескинен М. В. Поляки и финны. Гл. 5, гл. 7-1.

38 Kilpeläinen J. I. Rotuteoriat läntisistä suomalais-ugrilaisistä kansoista KeskiEuroopan antropologiassa 1800-luvulla ja suomalaisten reaktiot niihin // Mongoleja vai germaneeja? - rotuteorioiden suomalaiset / Toim. Kemiläinen A., Hietala M., Suvanto P. Helsinki, 1985. S. 163-194.

39 Инородцы Казанской губернии // Отечествоведение. Россия по рассказам путешественников и ученым исследованиям. Учебное пособие для учащихся. В 6-ти тт. / Сост. Д. Д. Семенов. СПб., 1866-1870. T. V. Великорусский край. СПб., М., 1869. С. 210.

40 Вишленкова Е. Визуальное народоведение. С. 95-116.

41 Подробнее о полемике по вопросу о происхождении великорусов и их этническом и антропологическим типе - в статьях: Найт H. Империя на просмотре: этнографическая выставка и концептуализация человеческого разнообразия в пореформенной России // Власть и наука, ученые и власть. Материалы международного научного коллоквиума. СПб., 2003. С. 437-457; Лескинен М. В. Великороссы/великорусы в российской научной публицистике (1840-1890) // Славяноведение. 2010. №6. С. 3-17.

42 В русском переводе: Швейгер-Лерхенфельд А. фон Женщина. Ее жизнь, нравы и общественное положение у всех народов земного шара. Пер. с нем. М. И. Мерцаловой. СПб., 1889. 
43 Плосс Г.Женщина в естествоведении и народоведении. В 3-х тт. СПб., 1898-1900. На русском языке вышло 6 изданий, последнее - в наше время (см. сноску 45).

44 Штрац К. Расовая женская красота. М., 2003.

45 Цит. по: Плосс Г. Женщина в естествоведении и народоведении. В 3-х тт. Сыктывкар - Киров, 1995. Репринт. изд. Т. 1. С. 84.

46 Там же.

47 Богданов А.В. Указ. соч. С. 133.

48 Штрац К. Введение // Штрац К. Расовая женская красота. М., 2003.

49 Там же.

50 Плосс Г. Указ. соч. С. 59-60.

51 Там же. С. 67-72. В контексте анализа народоописаний следует обратить внимание на эти черты противопоставления мужчин и женщин - ими в этнографических текстах, начиная с эпохи Просвещения, наделяются два европейских „племени“ - германцы и славяне (т.е. этническая оппозиция совпадает с дихотомией мужского и женского начал).

52 Там же. С. 85.

53 Там же. 99-101.

54 Шенк Б. Ментальные карты. Конструирование географического пространства в Европе со времени эпохи Просвещения // Новое литературное обозрение. 2001. № 6(52). С. 42-61. О процессе „регионализации“ Европе см. обзор Е. Сюча (Сюч Е. Три исторических региона Европы // Центральная Европа как исторический регион. М., 1996. С. 147-265).

55 О механизмах переориентирования ментальных карт в XVIII - начале XIX вв. с оппозиции юг/ север на запад / восток см., например: Вульф Л. Изобретая Восточную Европу. М., 2003; Шенк Б. Указ. соч. С. 42-48.

56 Саид Э. Указ. соч.; Lewis $R$. Gendering Orientalism: race, feminity and representation. Routledge, 1996. P. 12-52.

57 Подробно об этой традиции в Европе и России см., в частности: Богданов К. Климатология русской культуры. Prolegomena // Новое литературное обозрение. 2009. № 99. Текст доступен по адресу: http://magazines.russ.ru/ nlo/2009/99/bo7.html

58 Подробнее об этом см.: Лескинен М. В. Поляки и финны. Гл. 8.

59 См., например, Григорович Д. В. Нравы и обычаи разных народов. СПб., 1860; Природа и люди. Курс географии, содержащей описание частей света в физическом, этнографическом и политическом отношениях. В 2-х вып. СПб., 1868-1869 / Сост. и изд. А. Павловский. сочинения Э. Реклю, „Живописная Россия“, „Народы России. Этнографические очерки“. Подтверждением этому может служить также коллекция вырезок журнальных и газетных статей из фонда М. Д. Хмырова в ГПИБ, в котором теме „Женщина у древних и новых народов“ посвящены три объемных тома, а собрание „Женщина в России“ состоит из двух томов (Государственная публичная историческая библиотека. Фонд М. Д. Хмырова). О месте и роли истории женщин в историографии позитивизма см., в частности, краткую характеристику основных тенденций в: Пушкарева Н. Л. Русская женщина: история и современность. М., 2002. C. 11-23.

60 Реклю Э. Европейская Россия // Реклю Э. Земля и люди. Всеобщая география. В 19-ти тт. СПб., 1877-1896. T. V. Вып. II. СПб., 1883. Стлб. 105. 
61 Пиетров-Эннкер Б. „Новые люди“ России. Развитие женского движения от истоков до Октябрьской революции. М., 2005. С. 47-75.

62 Михайловский Н. К. Борьба за индивидуальность (1876) // Михайловский $H$. К. Полное собрание сочинений. В 6-ти тт. СПб., 1911-1913. Т. 1. СПб., 1911. C. 422-593.

63 Женщина // Энциклопедический словарь Ф. А. Брокгауза и И. Е. Ефрона. В XLI тт. (82 полутт.) / Под ред. Е. И. Андреевского. СПб., 1890-1907. Т. 22 (п/т XI a). СПб., 1894. С. 873-888. Подробная и наиболее полная библиография „женского вопроса“ во второй половине столетия приведена в: Пушкарева $H$. Л. Указ. соч.

64 Ефименко А. Я. Исследования народной жизни. Обычное право. М., 1888; Водовозова Е. Н. Жизнь европейских народов. В 3-х тт. СПб., 1875-1883; Она же. Как люди на белом свете живут. СПб., 1897-1904. Вып. 1-10; Пименова Э. К. Сербия. Историко-этнографический очерк. СПб., 1908; Buтmе Е. И. Путевые впечатления: Далмация, Герцеговина, Босния и Сербия. Лето 1902 г. Киев, 1902; Семенова-Тян-Шанская О. Указ. соч. и др.

65 Лескинен M. B. Теории племенной и национальной характерологии в русской славистике XIX в. // Славистика в центральноевропейском контексте. М., РГГУ (в печати).

66 Рябов О. В. „Матушка-Русь“. Опыт гендерного анализа поисков национальной идентичности России в отечественной и западной историософии. М., 2001. С. 23-30.

67 Анучин Д. Н. О задачах этнографии // Этнографическое обозрение. 1889. Вып. 1. С. 10.

68 Ламанский В. И. Об историческом изучении Греко-славянского мира в Европе. СПб., 1871. С. 69-74.

69 Пример этнографического обоснования такого рода содержится в упомянутой выше работе австрийского автора: Швейгер-Лерхенфельд А. фон Женщина... М., 1998. С. 561-563.

70 Об этом, в частности: Зенкин C. Н. Французский романтизм и идея культуры. Аспекты проблемы. М., 2001; Шёнле А. Подлинность и вымысел в авторском самосознании русской литературы путешествий. 1790-1840. СПб., 2004; Мочалова В. В. Миф Европы у польских романтиков // Миф Европы в литературе и культуре Польши и России. М., 2004. С. 129-146; Лескинен М. В. Миф Европы и Польша в „Записках“ В. С. Печерина // Там же. С. 161-181. Как верно отмечает В. Мильчина, объяснение особенностей образа жизни разных (чужих для описателя народов и племен) осуществлялось при помощи классификации черт „южан“ и „северян“, и во многих подобных сочинениях заменяло категорию национальности (Мильчина B. Сентиментальный национализм и многообразная русификация (Круглый стол „национализм в имперской России: идеологические модели и дискурсивные практики“, 2002 г.) // Ab Imperio. 2002. №2. C. 537-539).

71 Andrew J. Women in Russian Literature. 1780-1863. NY, 1988.

72 Буле О. Заметки о споре между la brune et la blonde в эпоху романтизма // Концепция и смысл. Сборник статей в честь 60-летия проф. В. М. Марковича. СПб., 1996. С. 28-47.

73 Там же. С. 30.

74 Лескинен М. В. Понятие „нрав народа“ в российской этнографии второй поло- 
вины XIX в. Описание малоросса в научно-популярной литературе и проблема стереотипа // Украина и украинцы: образы, представления, стереотипы. Русские и украинцы во взаимном общении и восприятии. М., 2008. С. 67-94; Она же. „Малороссийская народность“ в российской науке второй половины XIX века. Проблемы этнографического описания // Русские об Украине и украинцах. СПб., 2012. С. 244-283.

75 Mosse G. L. Nationalism and Sexuality. Middle Class Morality and Sexual Norms in Modern Europe. L., 1985; Lewis R. Op. cit.

76 См., в частности, статьи раздела „Island of the Sea of Others“ в сборнике: Images of the Other.

77 Подр. аргументация см: Лескинен М. В. „Прекрасная полька“ в русском воплощении: эволюция этногендерных стереотипов в образах и нарративах второй половины XIX в. // Россия - Польша: два аспекта европейской культуры. Царское село, 2012. С. 334-346; Она же. Гендерные особенности польского этнического типа в российских народоописаниях второй половины XIX в. // Amicus Poloniae. Памяти Виктора Хорева. М., 2014. С. 214-229.

78 Хорев В.А. Стереотип Польши и поляков в русской литературе накануне и после национально-освободительного восстания 1830 г. // Хорев В. А. Польша и поляки глазами русских литераторов. Имагологические очерки. М., 2005. С. 35-59.

79 Kukołowić T. Szacunek dla kobiety i starszego człowieka, umiłowanie dziecka // Wartości w kulturze polskiej. Lublin, 1993. S. 223-227; Prokop J. Kobieta Polka // Słownik literatury polskiej XIX wieku / Pod. red. J. Bachórza i A. Kowalczykowej. Wrocław. 2002.

80 Duszenko K. Polak i Polka w oczach Rosjan // Narody i stereotypy. Kraków, 1995. S. 158-164; Левкиевская E. E. Стереотип русско-польской любви в русской литературе XIX-XX вв. // Россия - Польша. Образы и стереотипы в литературе и культуре. М., 2002. С. 192-200; Мочалова В. В. Образ Марины Мнишек в историографии и литературе // Studia polonica. К 70-летию В. А. Хорева. М., 2002. С. 372-397; Сараскина Л. „Гордая полячка“ в русской истории // Dusza polska i rosyjska. Spójrzenie współczesne / Pod red. A. de Lazari. Łodż, 2003. S. 140-149.

81 Цит. по: Левкиевская Е. Е. Стереотип русско-польской любви. С. 193.

82 Плосс Г. Указ. соч. С. 102.

83 Цит. по: Плосс Г. Указ. соч. С. 103-104. Интересно отметить, что в русском переводе немецкоязычного оригинала сочинения А. фон ШвейгерЛерхенфельда 1882 года в данном фрагменте сравнение с „северной русской женщиной“ снято - скорее всего, редактором российского издания. (Швейгер-Лерхенфельд А. фон Указ. соч. М., 1998. С. 636.)

84 Лескинен М. В. Поляки и финны. Гл. 6-2.

85 Пуцыкович Ф. Ф. Поляки. СПб., 1899. С. 11

86 Скальковский К. А. Несколько дней в Варшаве // Скальковский К. А. Новые путевые впечатления. СПб., 1889. С. 61-132. С. 84.

87 Лескинен М. В. Поляки и финны. Гл. 6-1.

88 Кюн К. Народы России. СПб., 1888. С. 54.

89 Варшава // Отечествоведение. Т. 4. Восток и Запад (Сибирь и Западный край). СПб., 1867. С. 187-189; Пуцыкович Ф.Ф. Указ. соч. С. 11; Сно Е.Э. На за- 
падных окраинах. Поляки и литовцы. (Серия „Рассказы о родной стране и ее обитателях"). СПб., 1904. С. 10; Водовозова Е. Н. Поляки // Водовозова Е. Н. Как люди на белом свете живут. Чехи - поляки - русины. СПб., 1905. С. 126127.

90 Поляки (Народы России. Этнографические очерки) // Природа и люди. 1878. №4. С. 1.

91 Поляки // Народы России. Живописный альбом. В 2-х вып. СПб., 1877-1878. Вып. 1. СПб., 1877. С. 58.

92 Варшава. С. 188-189.

93 Скальковский К. А. Несколько дней в Варшаве. С. 84-85.

94 Михневич В. О. Варшава и варшавянки. Наблюдения и заметки. СПб., 1881. С. 50.

95 Дедлов В. (В. Л. Кигн) У поляков // Дедлов В. Вокруг России. Польша Бессарабия - Крым - Урал - Финляндия - Нижний. Портреты и пейзажи. СПб., 1895. С. 7-95. С. 20.

96 Скальковский К. А. Несколько дней в Варшаве. С. 84, 86.

97 Варшава. С. 189.

98 Поляки // Народы России. С. 60.

99 Скальковский К. А. Несколько дней в Варшаве. С. 87.

100 Швейгер-Лерхенфельд А. фон Указ. соч. С. 537-539; 636.

101 Макушев В. Поляки в России // Голос. 1873. № 160. 11 июня /23 июня. С. 1-3. С. 2. 102 Михневич В. О. Указ. соч. С. 51.

103 Варшава. С. 189.

104 Пржецлавский О. А. Калейдоскоп воспоминаний // Поляки в Петербурге в первой половине XIX века / Сост., предисл., подготовка текста воспоминаний О. А. Пржецлавского и коммент. А.И. Федуты; пер. воспоминаний С. Моравского, Т. Бобровского и А.-Г. Киркора с пол. Ю. В. Чайникова. М., 2010. С. 29-168. На русском языке фрагменты этих воспоминаний публиковались в 1872, 1874, 1876 и 1783 гг. на страницах „Русского архива“ и „Русской старины“ (Там же. С. 733), а потому Макушев вполне имел возможность ознакомиться с самыми ранними заметками еще до сотрудничества с „Голосом“.

105 Там же. С. 35.

106 Там же. С. 140.

107 Там же. С. 140-141.

108 Лескинен М. В. Миф Европы и Польша в „Записках“ В. С. Печерина.

109 Свирида И. И. О гедонистической ипостаси топоса Варшавы // Studia Polonica. К 70-летию В. А. Хорева. М., 2002. С. 398-408.

110 Дедлов В. Указ. соч. С. 19, 20.

111 Реклю Э. Европейская Россия. Стлб. 710.

112 Там же.

113 Подробный анализ путешествия В. Дедлова по Польше см.: Хорев В. А. „Польский вопрос“ в России после восстания 1863 г. // Хорев В. А. Польша и поляки глазами русских литераторов. С. 78-101.

114 Дедлов В. Указ. соч. С. 19. 
115 Михневич В. О. Указ. соч. С. 50.

116 Там же. С. 51.

117 Скальковский К. А. 0 женщинах. С. 269.

118 Лескинен М. В. Понятие „нрав народа“ в российской этнографии второй половины XIX в. Описание малоросса в научно-популярной литературе.

119 Александровский И. С., Лескинен М. В. Указ. соч.

120 Левкиевская Е. Стереотип украинца в русском сознании // Украина и украинцы. С. 154-176.

121 Другое путешествие князя П. И. Шаликова в Малороссию. М., 1804. С. 4.

122 Так пишет, анализируя работы первого десятилетия XX в., написанные украинским антропологом Г. Вовка, М. Могильнер (Могильнер M. Homo Imperii. История физической антропологии в России. М., 2008. С. 294).

123 Екельчик C. Человеческое тело и национальная мифология: некоторые мотивы украинского национального возрождения XIX века // Ab Imperio. 2006. № 3. C. 23-54.

124 Подробнее об этом: Лескинен М. В. Поляки и финны. С. 105-111; Она же. Великороссы /великорусы в российской научной публицистике (18401890) // Славяноведение. 2010. № 6. С. 3-17.

125 Цит. по: Плосс ГУказ. соч. С. 104. Здесь снова необходимо оговориться, что в русском переводе текста Швейгер-Лерхенфельда глава о русских (российских) женщина полностью отсутствует. Издатель А. Ф. Девриен помещает на ее место статью В. И. Немировича-Данченко, аргументируя необходимость замены тем, что „внутреннее понимание нашей женщины, каким владеет русский читатель, конечно, недоступно иностранцу, хотя бы и ученому“ (Предисловие // Швейгер-Лерхенфельд А. фон Указ. соч. С. VI).

126 Руководство к изучению русской земли и ее народонаселения. По лекциям М. Владимирского-Буданова сост. и издал преподаватель гимназии во Владимирской киевской военной гимназии А. Редров. Киев, 1867. С. 261.

127 Очерк I. Малороссийское племя. С. 6.

128 Руководство к изучению русской земли и ее народонаселения. С. 324.

129 Очерк I. Малороссийское племя // Живописная Россия. Отечество наше в его земельном, историческом, племенном, экономическом и бытовом значении. Под ред. П. П. Семенова. В 12-ти тт. Т. 5. Малороссия, Подолия и Волынь (Полтавская, Черниговская, Волынская, Херсонская и Киевская губернии). Ч. 1. СПб.-М., 1897 (автор - Д. Л. Мордовцев). С. 6.

130 Там же. С. 16.

131 Тихорский Н. Повесть А. Кузьмича „Казаки“ (СПб., 1843). Рецензия // Маяк. 1843. Кн. XXIV. Гл. IV. С. 75-147. С. 110.

132 Очерк I. Малороссийское племя. С. 9, 19.

133 Там же. С. 9.

134 Там же. С. 16.

135 Там же.

136 Чубинский П. П. Труды этнографическо-статистической экспедиции в западно-русский край, снаряженной Императорским Русским географическим обществом. В 7-ми тт. СПб., 1872-1874. Т. 7. Вып. 2. СПб., 1872 (пагинация выпусков - сплошная). С. 354. 
137 Очерк I. Малороссийское племя. С. 8.

138 Там же. С. 19.

139 Там же. С. 8.

140 Плосс Г. Указ. соч. С. 102.

141 Реклю Э. Земля и люди. Всеобщая география. В 19-ти тт. СПб., 1898-1901. Кн. 1. Т. 1. СПб., 1893. Стлб.250.

142 Швейгер-Лерхенфельд А. фон Указ. соч. С. 632.

143 Там же.

144 Некоторые главные тенденции в описании сербов в источниках данного жанра проанализированы в работах А. Л. Шемякина. В частности: Шемякин А. Л. Относительность самооценок: сербский крестьянин глазами русских путешественников // Славянский мир в глазах России. М., 2011. С. 175-194.

145 Ровинский П. А. Белград. Его устройство и общественная жизнь // Русские о Сербии и сербах / Сост., подготовка к изданию, введение и заключительная статья А. Л. Шемякина, комментарии А. А. Силкина, А. Л. Шемякина. СПб., 2006. С. 59.

146 Скальковский К. А. О женщинах. С. 280.

147 Мураневич А. Й. Русско-балканский торговый вопрос // Там же. С. 280; Вейнберг Р. Сербы и Сербия (Этнографический очерк) // Там же. С. 471.

148 Мещерский В. П. Правда о Сербии. Письма. Письмо одиннадцатое // Там же. C. 158:

149 Вейнберг Р. Указ. соч. С. 471.

150 Скальковский К. А. О женщинах. С. 277.

151 Водовозова Е. Н. Как люди на белом свете живут. Болгары, сербы, черногорцы. СПб., 1898. С. 105-125.

152 Пименова Э. К. Указ. соч. С. 19.

153 Саид Э. Указ. соч. 


\section{Резиме}

Др Марија Лескинен

\section{Карактерологија Словена у руској интерпретацији: начини представљања родних одлика „етнички другог“ у другој половини XIX века}

Кључне речи: руска етнографија XIX века, словенске студије, национални карактер, родни типови, имагологија, антропоестетика

У чланку се разматрају основне тенденције етнокултурних представа (описивање спољашности и карактера) другог код словенских народа у руским етнографским радовима XIX века. Анализирани су теоретски ставови и пракса европског етнографског дискурса тог доба. У центру пажње се налазе особине родних образаца трију словенских етничких типова (Западних, Источних и Јужних Словена на примеру Пољакиња, Малорускиња и Српкиња) у контексту општих представа о природи националне специфичности. Приказана је и специфична хијерархија образаца, која је условљена општеетничким карактеристикама словенских народа и диктирана степеном њихове етнокултурне блискости. 